\title{
معدل الفائدة الفني وتأثثيره علي قسط التامين علي الحياة
}

ايمن احمد عبد الحميد التجار

معيد بكلية التجارة

جامعة جنوب الوادي

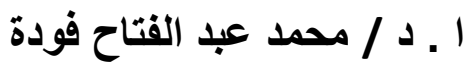

أستاذ الرياضيات والاحصاء الاكتواري

كلية التجارة - جامعة المنصورة

ملخص البحث

يعتبر معدل الفائدة الفني العنصر الثاني الذي يحسب علي أساسه قسط التأمين علي الحياة , وتنتشأ

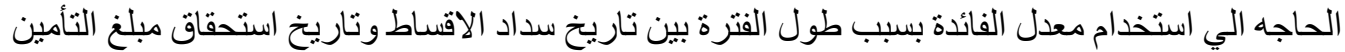

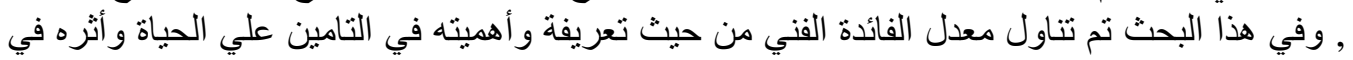

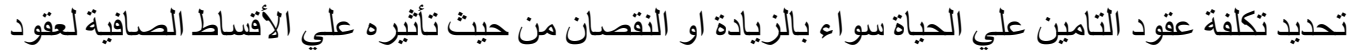

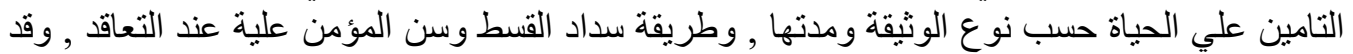

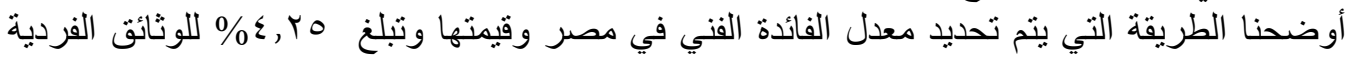

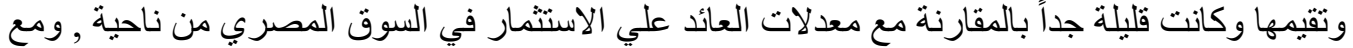

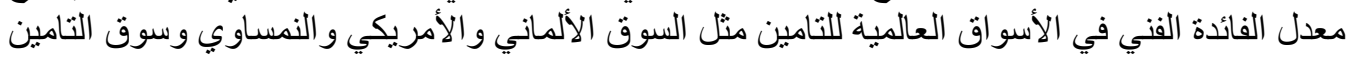

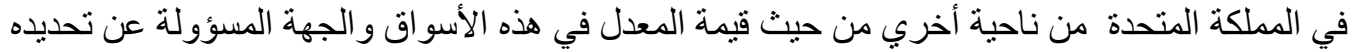

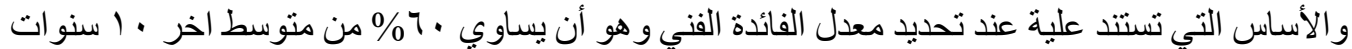

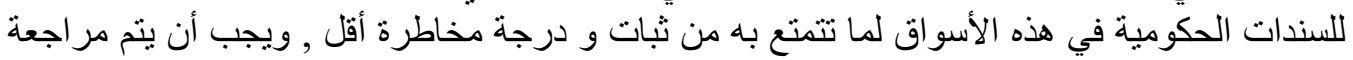

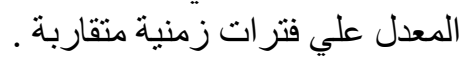

\section{$\underline{\text { Abstract }}$}

The technical interest rate is the second element on the basis of which the life insurance premium is calculated, and the need to use the technical interest rate arises due to the long period between the date of payment of premiums and the date of maturity of the insurance amount. In this research, the technical interest rate was studied in terms of its definition and importance in life insurance. And its impact in determining the cost of life insurance contracts, whether by increase or decrease in terms of its impact on the net premiums of life insurance contracts, according to the type and duration of the policy, the method of payment of the premium and the age of the insured when contracting, We have clarified the way in which the technical interest rate in Egypt is determined and its value is $\leqslant, r 0 \%$ for individual insurance policies and 
evaluated, and it was very few compared to the rates of return on investment in the Egyptian market on the one hand, and with the technical interest rate in the global insurance markets such as the German, American, Austrian and insurance market in the United Kingdom On the other hand, in terms of the value of the rate in these markets and the party responsible for determining it and the basis on which it is based when determining the technical interest rate, which is equal to $7 . \%$ of the average of the last 1 - years of government bonds in these markets due to its stability and a lower degree of risk, The technical rate should be reviewed at frequent intervals.

\section{- 1}

ترتكز نظريه الفو ائد علي ان راس المال باعتباره عاملاً مهما من عو امل الإنتاج لابد

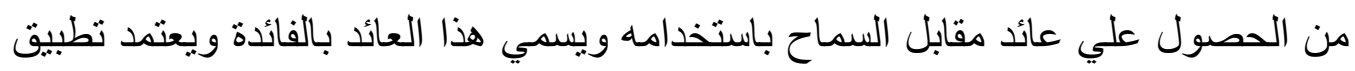
الفائدة علي القاعدة الأساسية التي تربط بين القيمة وتاريخ الاستحقاق .

ونظر الما يمثله التأمين علي الحياه نسبة لا يستهان بها في سوق التأمين المصرية ،

لللك لابد من الاهتمام بأمو ال تأمينات الحياه وتوظيفها في اوعيه استثماريه مناسبه تعود

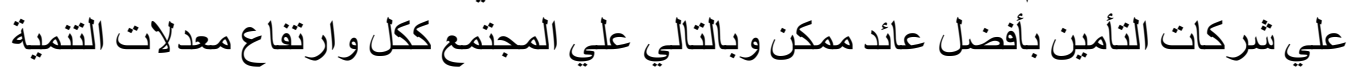
الاقتصادية وتحسين مستويات المعيشة بين افر اده ـ

و نتيجة لطول الفترة بين تاريخ أبر ام العقد وتاريخ استحقاق مبلغ التأمين في التأمين علي

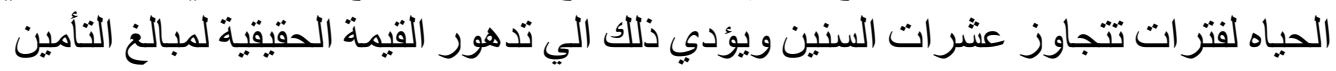
وذللك بسبب تعرض القوه الثر ائية للنقود للانخفاض المستمر بسبب عو امل التضخئم , ولذلك فئل

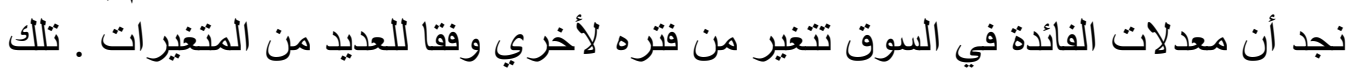

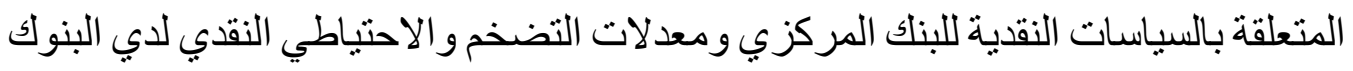
و الطلب علي النقود من المستثمرين الأمر الذي يؤثر من شأنه علي تغيير معدل الفائدة

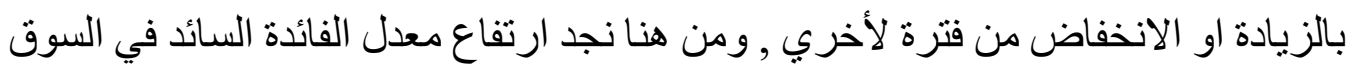

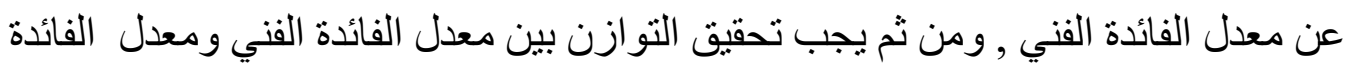

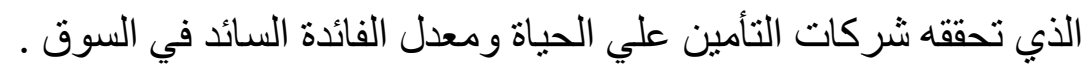

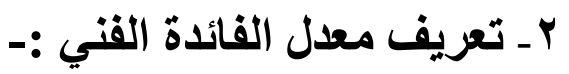


ويعرف معدل الفائدة الفني: النسبة المئوية للفائدة التي تضيفها شركة التأمين لحساب

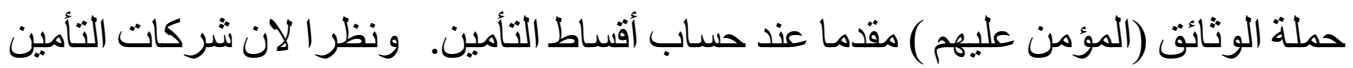

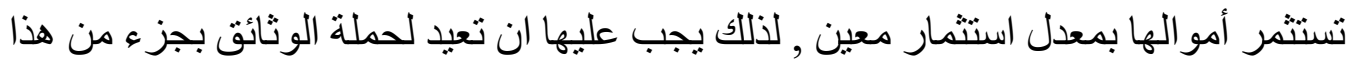

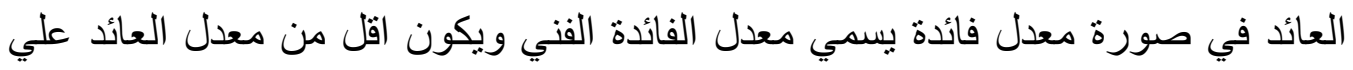

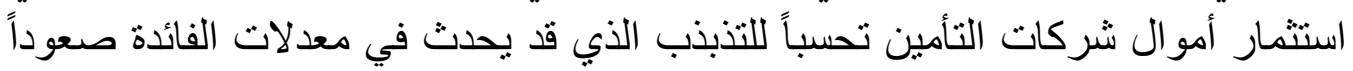

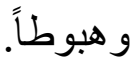

ولعل المبرر في استخدام معدل الفائدة الفني عند حساب أقساط التأمين على الحياة هو

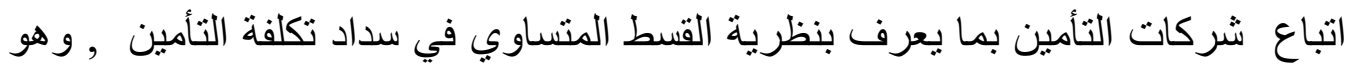

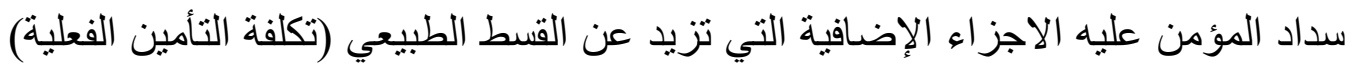

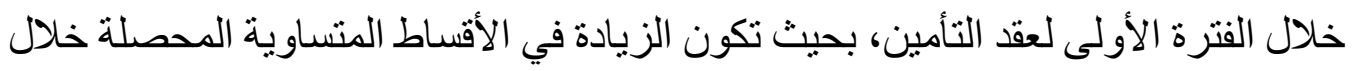

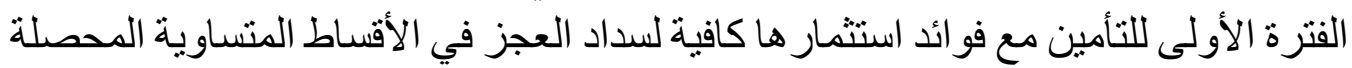

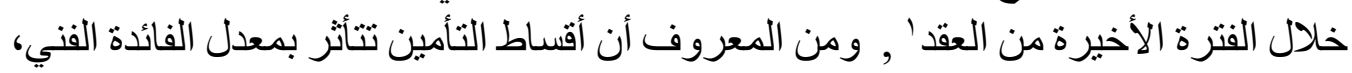
فكلما ازد هذا المعدل كلما نقص مقدار قسط التأمن التمين، و العكس صحيح..

ولما كانت أقساط عقد التأمين يتم تحصيلها مقدما من المؤمن لهم ـ فانه يكون بمقدور

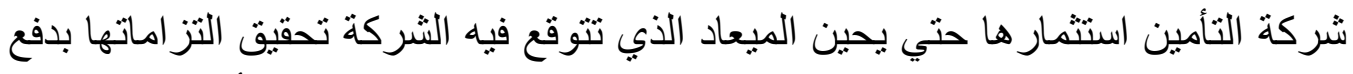

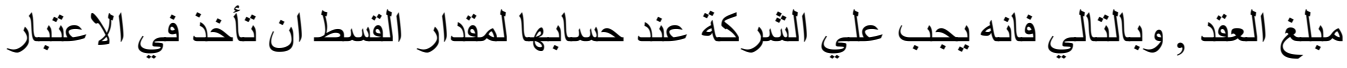

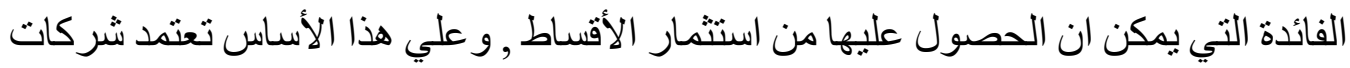

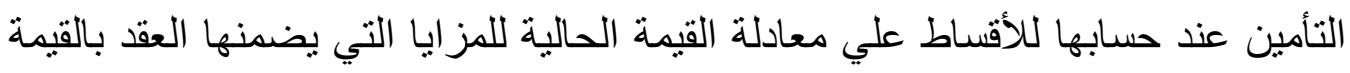

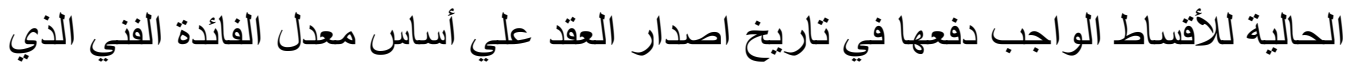
تحدده الثركة , ويتم تحديد هذا المعدل في ضوء العائ العائد الذي يمكن تحقيقه في المستقبل ' ل و لا يجب أن نخلط بين معدل الفائدة الفني الذي يحسب علي اساسه القسط المستخدم في

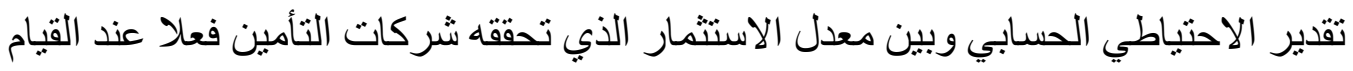

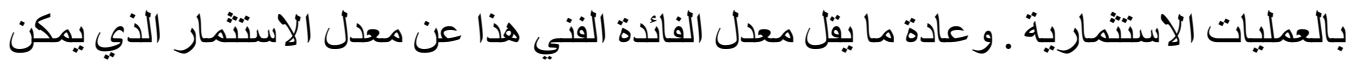
تحقيقه فعلا , ويكمن السبب ور اء ذللك الي اسلوب الحيطة و الحذر الذي تتبعه شركات التأمين

عبد احمد ابو بكر ,نموذج احصائي للتنبوء بمعدلات العائد علي الأستثمار في شركات التأمين علي الحياه بالسوق المصري ,'

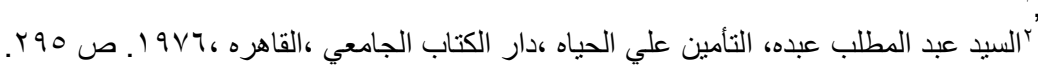


علي الحياه عند تقدير ها للمعدل الفني , و ايضاً مجمو عة العو امل التي تؤثر علي معدل الفائدة

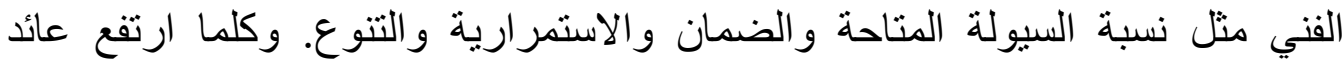

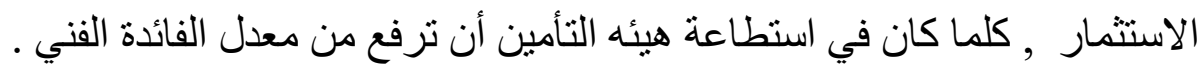

وقد تستخدم شركات التأمين اكثر من معدل واحد في حساب أقساط العقود المختلفة التي

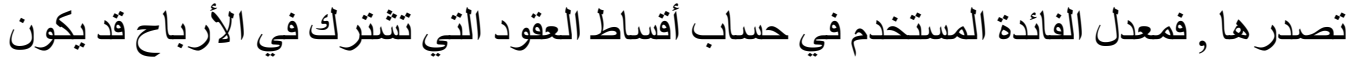

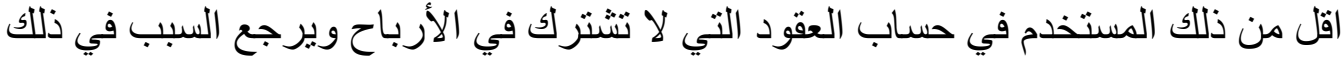

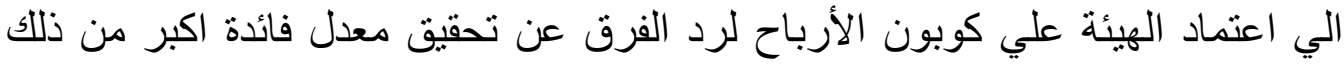

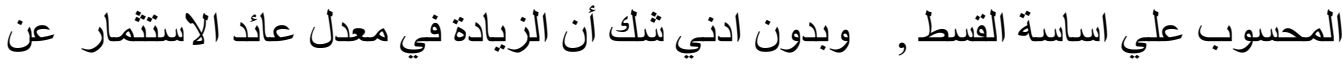

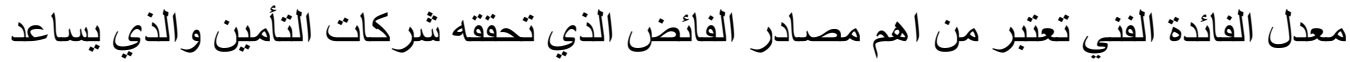

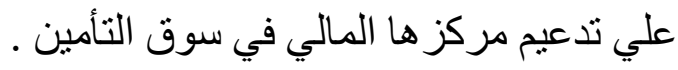

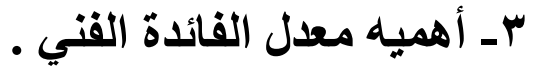

من المعروف أن شركات التأمين تؤدي دور ا هاما وبارز اللاقتصاد القو مي ،سواء كأن

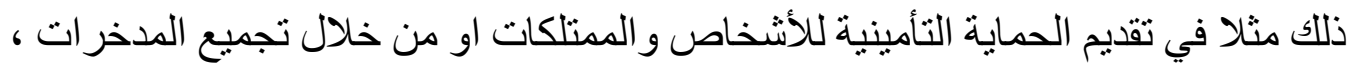

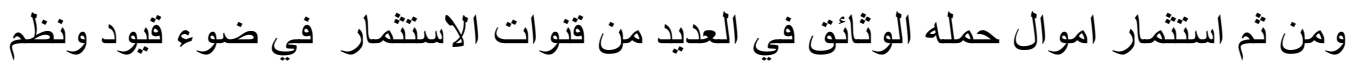
الاشر اف و الرقابة بهدف الحصول علي اعلي عائد ممكن و اقل مخاطره ممكنه . ويعتبر معدل الفائدة الفني جزء مهم في كل عقد من عقود التأمين علي الحياة , لأنه الفها

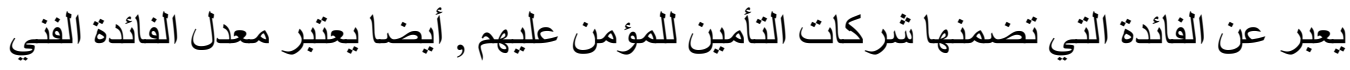

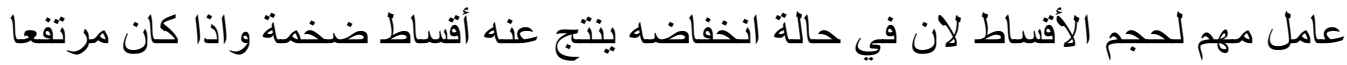

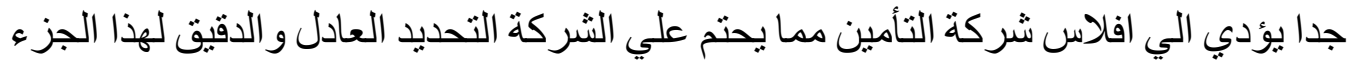

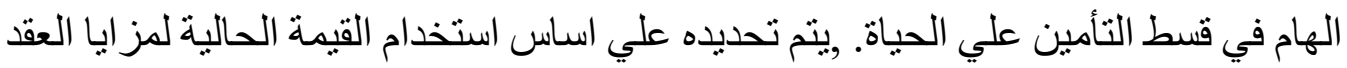

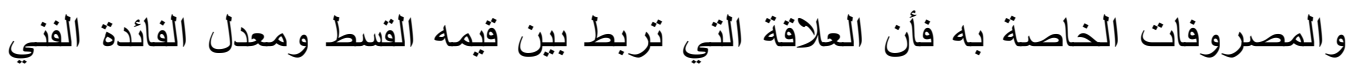

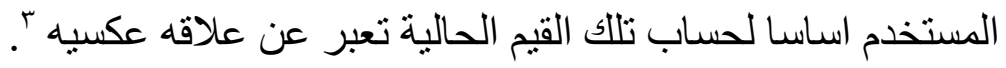

r Koller, M. Stochastic models in life insurance. Springer Science \& Business Media.pag rr. $(r \cdot \mid r)$. . 
ويتوقف تأثثير التغير في معدل الفائدة الفني علي الاقساط الصافية علي الأهمية النسبية

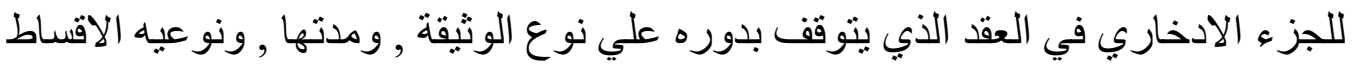

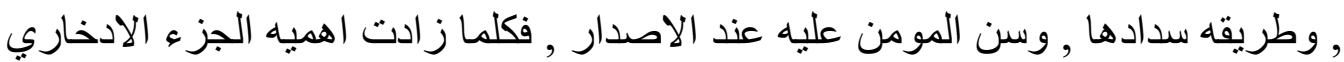
زاد تأثير التغير في معدلات الفائدة علي الاقساط الصافية وهذا سوف نوضحه في الأجزاء

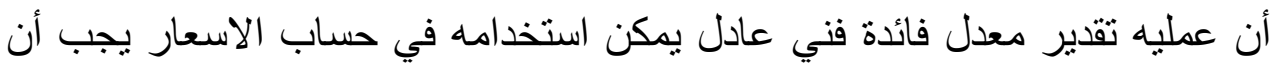

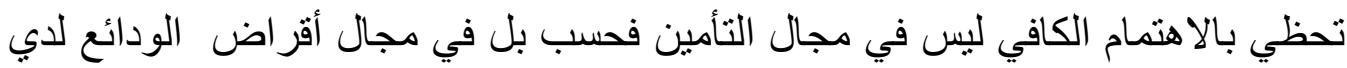
البنوك حيث أن المستثمر ير غب في معرفه وتقدير التدفقات النقدية الداخلة والخارجة ولئ وهذا

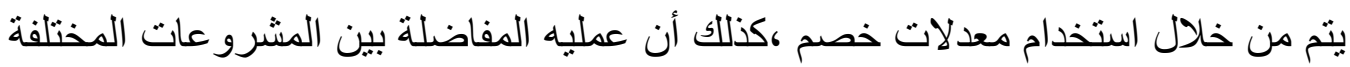
تعتمد علي استخدام معدلات خصم حيث يعد تطوير نماذج خصم التدفقات النقات النقدية الركيزة

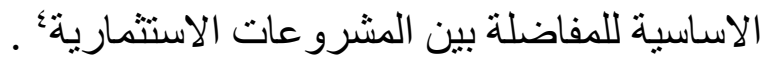

ويعتمد تحديد معدل الفائدة الفني اساسا علي معدل الاستثمار الصافي الذي يمكن أن الن النيا

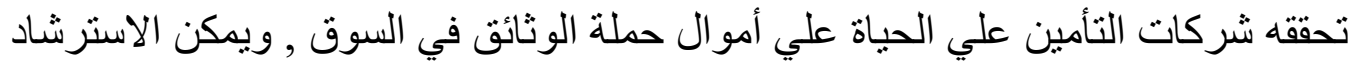

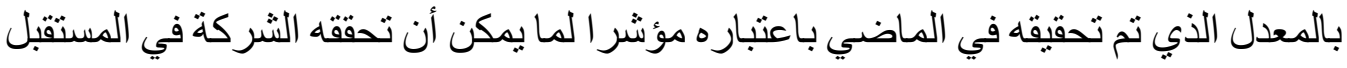

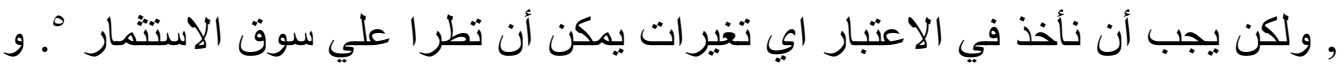

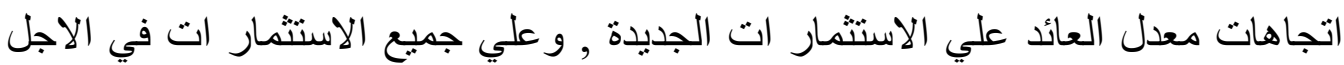

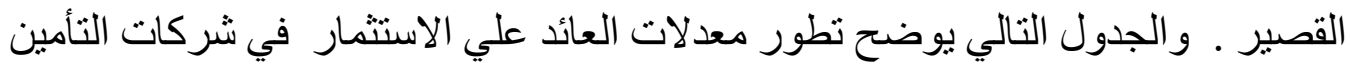

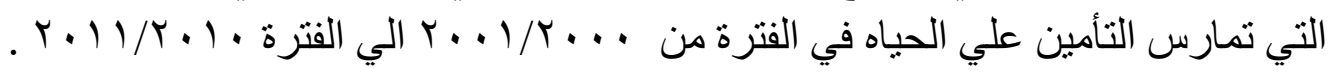

\section{جدول رقم (1) (1) (1)}

معدل العائد على استثمار أموال التأمين على الحياة فى شركات التأمين المصرية

؛. محمد غازي صابر ، تقدير معدل الفائدة الفني بأستخدام الدالة الاحتمالية لتوزيع باريتو، افاق جديده للار اسات التجاريه

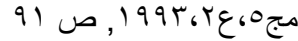

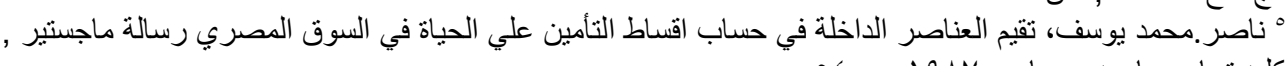




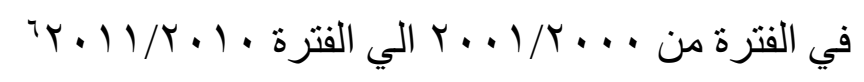

\begin{tabular}{|c|c|}
\hline معلة الوثنائق(\%) معار اموال & السنة \\
\hline $1 \cdot, 109$ & $r \ldots 1 / r \ldots$ \\
\hline$\wedge, \wedge r$ & $r \ldots r / r \ldots l$ \\
\hline 9,11 & $r \ldots r / r \ldots r$ \\
\hline $11, r$ & $r \ldots \varepsilon / r \ldots r$ \\
\hline $1 \cdot, Y T$ & $r \ldots \theta / r \ldots \varepsilon$ \\
\hline 11,97 & $r \ldots T / r \ldots 0$ \\
\hline $11, V$ & $r \ldots v / r \ldots q$ \\
\hline $9,0 Y$ & $r \ldots \Lambda / r \ldots v$ \\
\hline $11, r$ & $r \ldots q / r \ldots 1$ \\
\hline $1 \cdot, 1$ & $r \cdot 1 \cdot / r \cdot . q$ \\
\hline 11,1 & $r \cdot 1 \cdot / r \cdot 11$ \\
\hline
\end{tabular}

من الجدول السابق يتضح أن هناك تقلب في معدلات العائد على استثمار امو ال التأمين

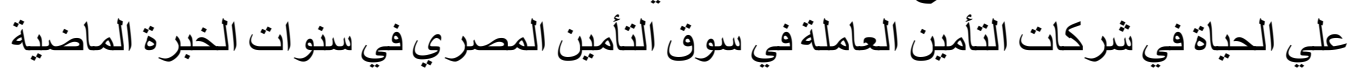

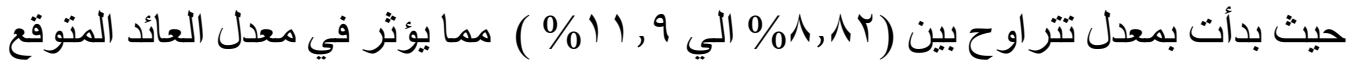

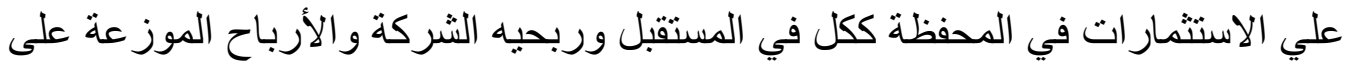

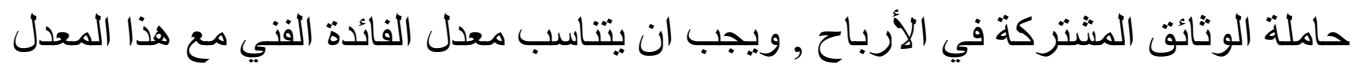

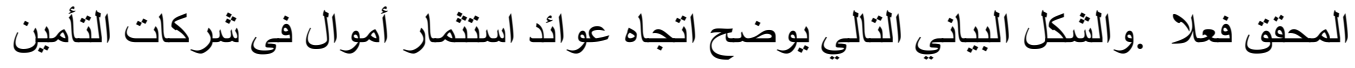

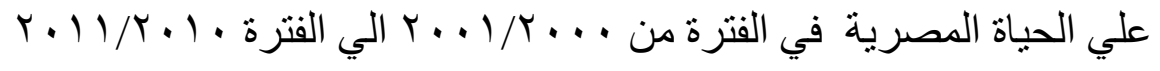




\section{شكل رقم (1)}

معدل العائد علي الاستثمار المحقق في شركات التأمين علي الحياة

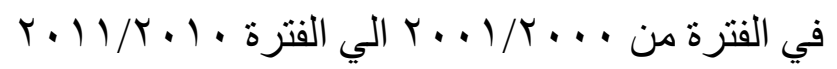

$$
\text { معدل العائد علي الاستثمار المحقى في شركات التأمين علي الحياة }
$$

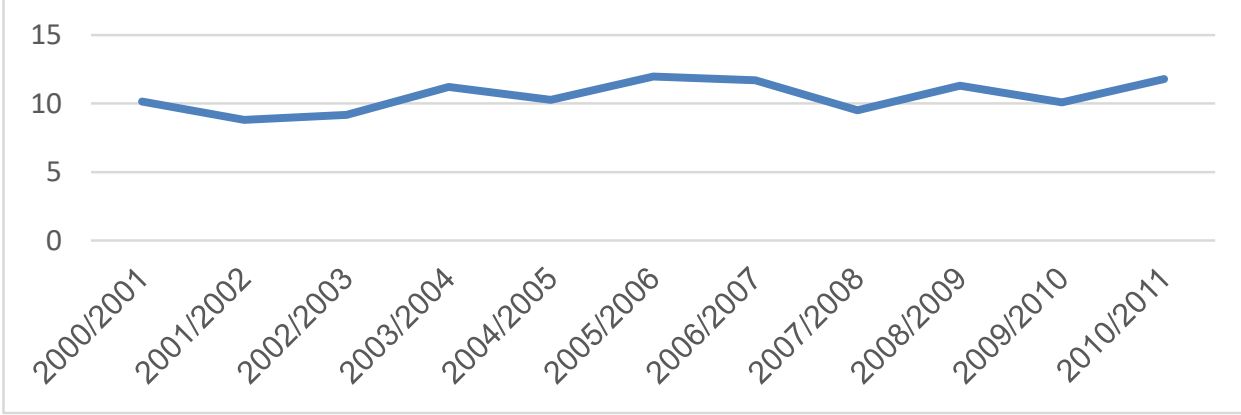

$$
\text { الثكل من اعداد الباحث من خلال استخدام بر امج الحاسب الالي }
$$

من الشكل رقم (1) يوضح التذبذب في معدلات العائد علي أمو ال شركات التأمين علي

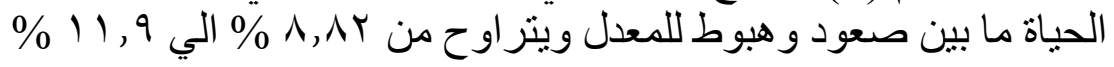

ويري الباحث نتيجة لتذبذب معدل العائد علي أمو ال شركات التأمين و عدم ثبات المعدل ولو لفترة صغيرة يجب أن بتسم معدل الفائدة الفني بالمرونة الكافية التي تمكنه من الأستجابه للتغير ات في السوق ككل وذلك من خلال تقدير معدل الفائدة الفني طبقا لمعدل العائد علي الاستثمار لكي تستطيع مواجهه اي تقلبات في أسعار الفائدة السائدة في السوق من فئن ناحيه

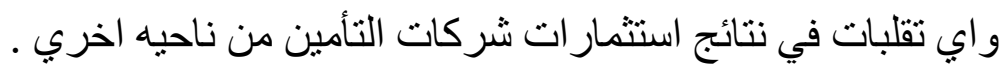

وفي السوق المصري فتحديد معدل الفائدة الفني يتم عن طريق الخبير الاكتواري لكل

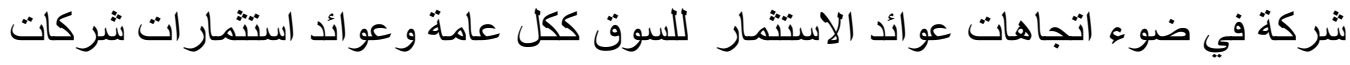
التأمين خاصة لمراعاة النسب والاوجه القانونية التي تحددها الهيئة ويكون دور الهيئة 


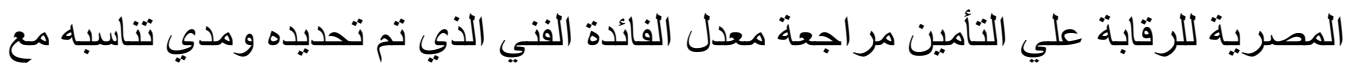

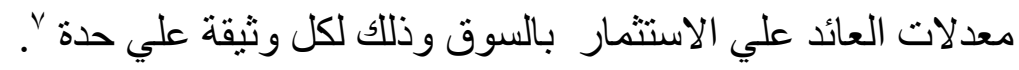

ويلاحظ أن شركات التأمين قد تستخدم معدل فائدة في حساب اقساط عقود التأمين حال

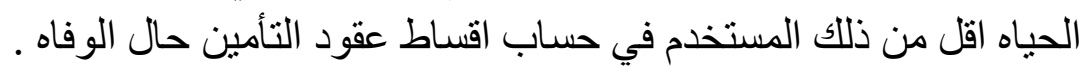

ولما كأن معدل الفائدة الفني يمثل عنصر ا أساسيا في حساب الاقساط عقود التأمين علي

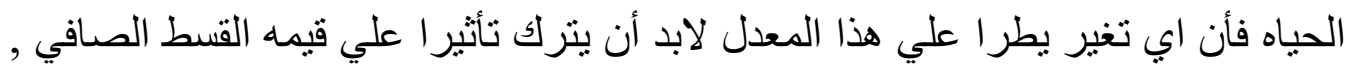

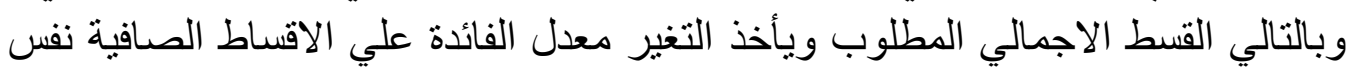

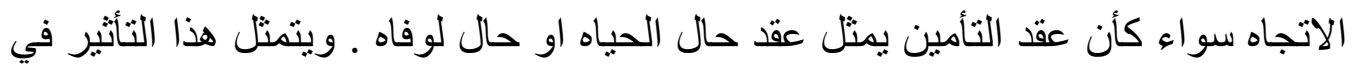
علاقه عكسيه بين معدل الفائدة ومقدار القسط المطلوب الناه

ومن المعروف أن معظم المهتمين في مجال التأمين، مع تباين المجتمعات التي ينتمون

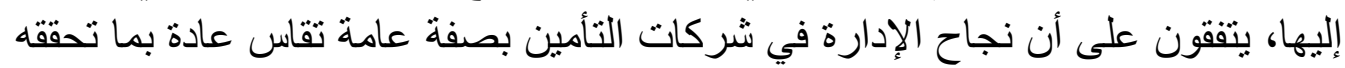

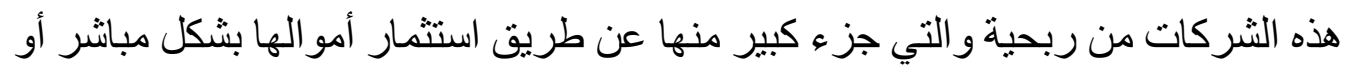

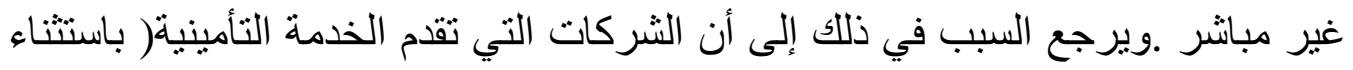

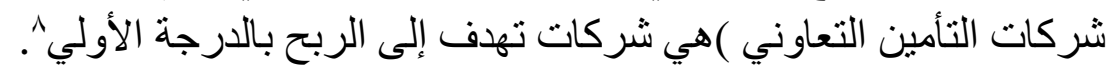

ويتكون لدي شركات التامين أمو ال ضخمه تمثلك منها شركة التأمين جزء بـ بسيط، أما

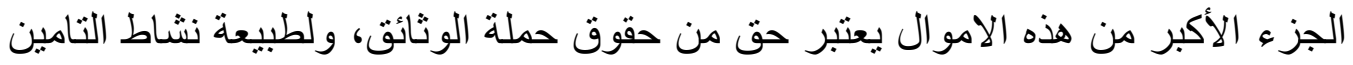

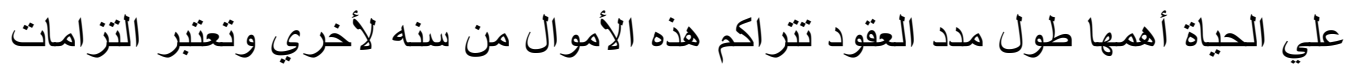

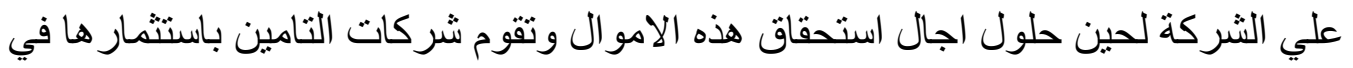

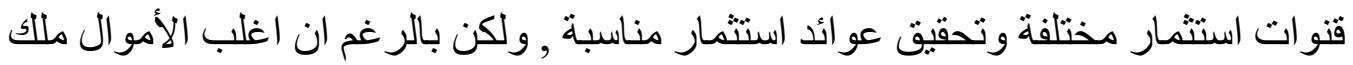

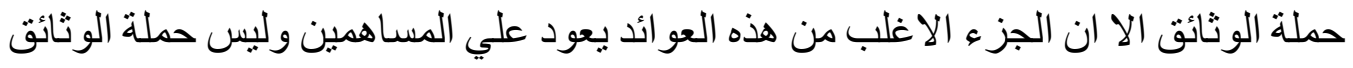

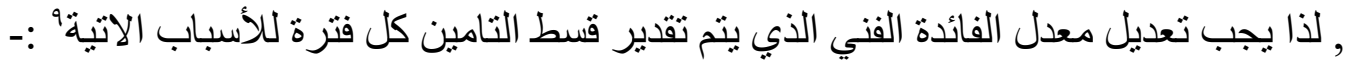

\footnotetext{
" "مقابلة مع السيد الأستاذ الدكتور رئيس قطاع الثؤن الاكتو ارية و إعادة التأمين بشركة مصر لتامينات الحباة .

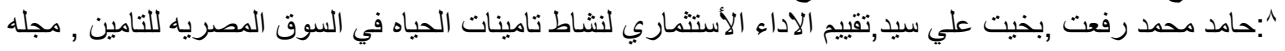

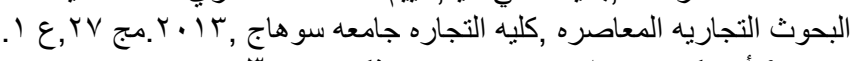

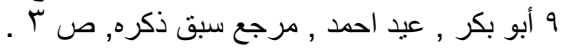


مو اكبه التغيرات السريعة في اسعار الفائدة في قنو ات الاستثمار البديلة .

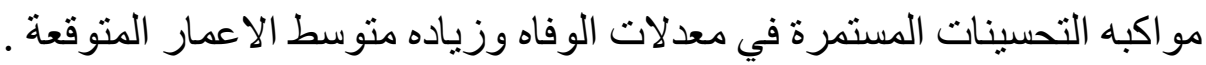

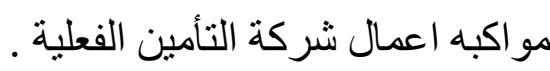

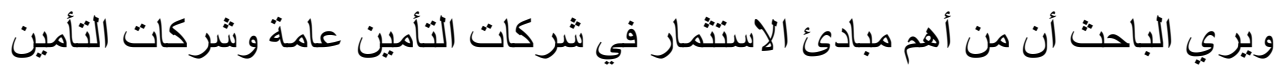

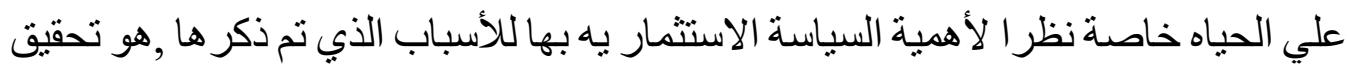

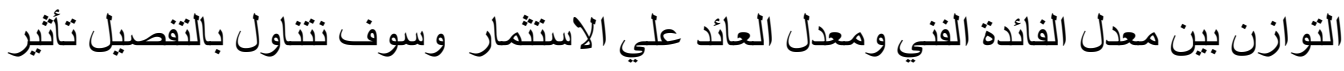

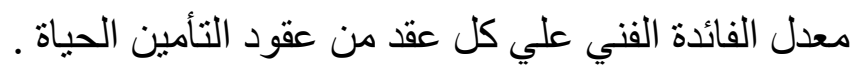

ץ:- اثر تغير معدل الفائدة القني علي الأقساط الصافية لعقود التأمين :-

سبق وان ذكرنا ان بنوقف تأثثر التغير في معدلات الفائدة علي الأقساط الصافية علي

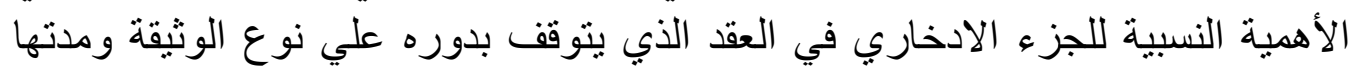

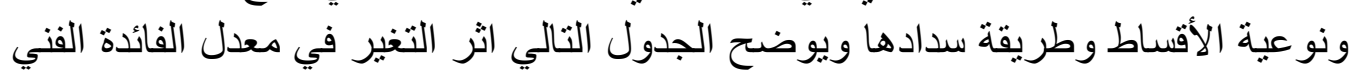

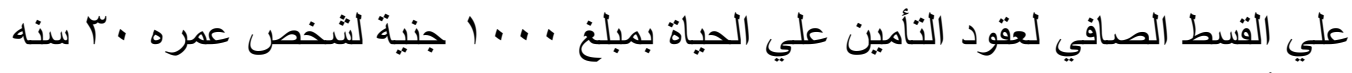

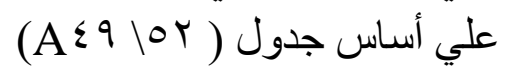

جدول رقم (r) (r) (1)

اثر التغير في معدل الفائدة الفني علي القسط الصافي لعقود التأمين علي الحياة بمبلغ جنية

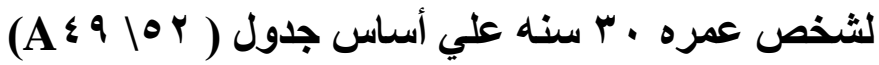

\begin{tabular}{|c|c|c|c|c|}
\hline \multirow{2}{*}{ 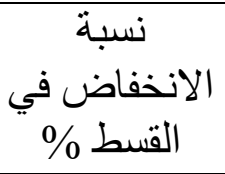 } & \multirow[t]{2}{*}{ القسطين } & \multicolumn{2}{|c|}{ القسط الصافي علي أساس } & \multirow[t]{2}{*}{ نوع التأمين } \\
\hline & & $\% \varepsilon, \cdot r o$ & $\%$ r, ro & \\
\hline$r, T V$ & . vo & 1,971 & $r, \cdot \varepsilon \varepsilon$ & مؤقت لمدة • ب سنه \\
\hline $19,1 V$ & r, YYq & $9, \varepsilon \cdot 1$ & $11, \pi$. & مدي الحياة بأقساط \\
\hline$r \varepsilon, 9 Y$ & $\varepsilon, 0 \leqslant \leqslant$ & 14,794 & IA, $Y$ TV & 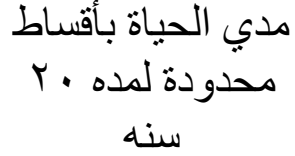 \\
\hline
\end{tabular}




\begin{tabular}{|c|c|c|c|c|}
\hline I. & $r, V Y I$ & $r r, r \cdot \tau$ & $r q, \cdot Y V$ & مختلط لمدة ، بنه \\
\hline
\end{tabular}

توضح البيانات الواردة من الجدول السابق الاتي :_

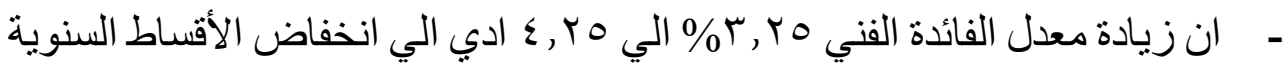

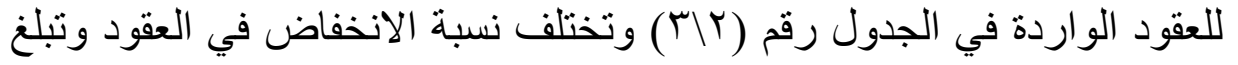

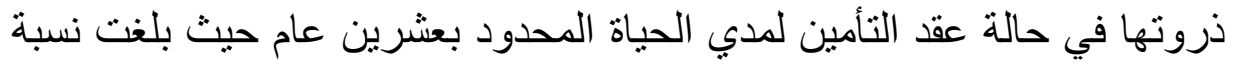

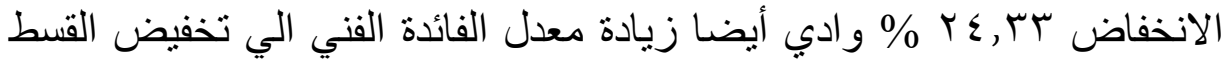

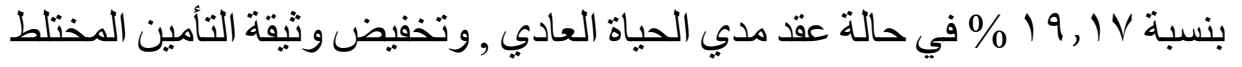

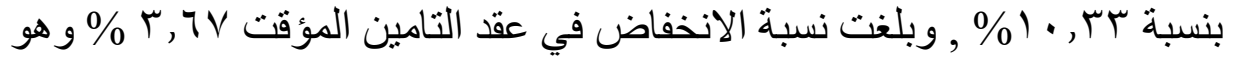

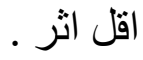
- وبالنظر الي نسبة الانخفاض نجد أن تزداد نسبة الانخفاض بصورة اكبر في حاله

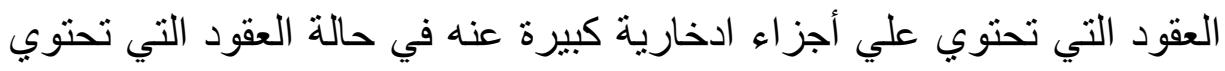

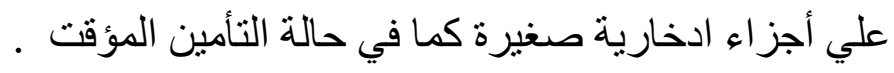

و لا يقتصر تأثير تغير معدل الفائدة الفني علي نوع العقد فقد ولكن يختلف أيضا باختلاف ولثاف

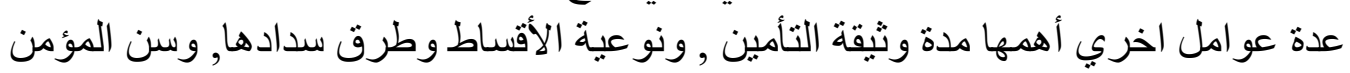

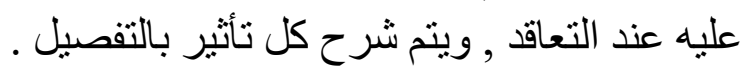

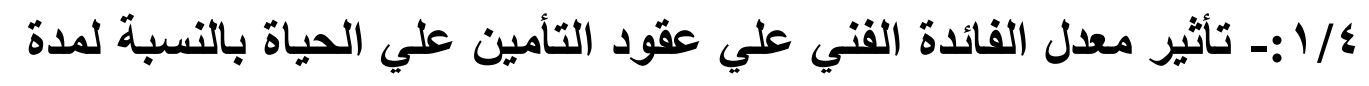
وثيقة التأمين

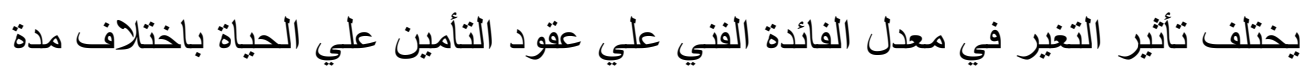

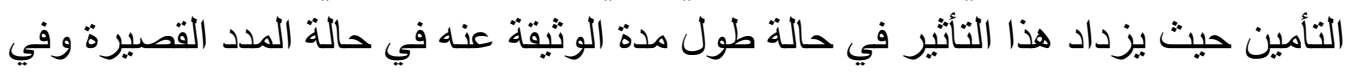

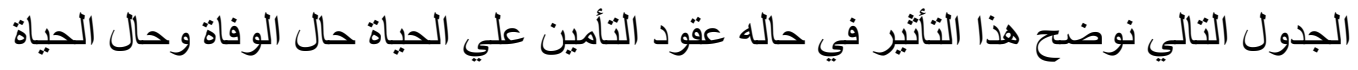
. Sest 


\section{الجدول رقم (๕)}

اثر التغير في معدل الفائدة الفني علي الأقساط السنوية الصافية لوثنقة تامين علي الحياة

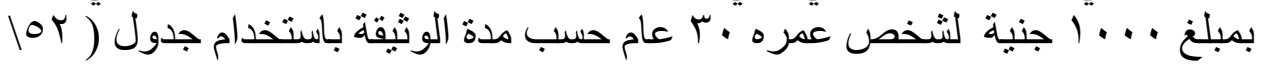

$$
(A \leqslant q
$$

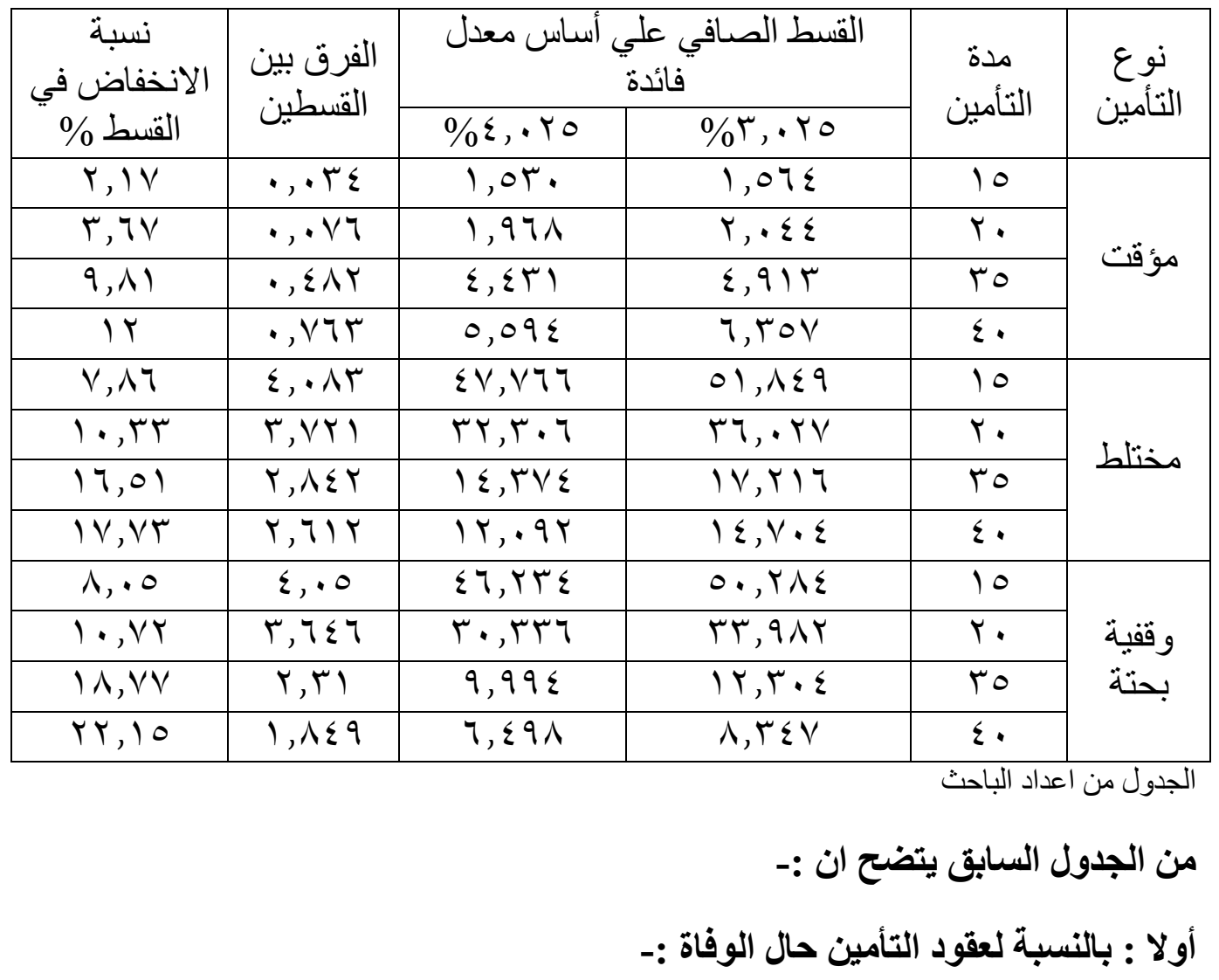


- بالنسبة لوثيقة التأمين المؤقت نجد ان نسبة الانخفاض في قيمة القسط السنوي

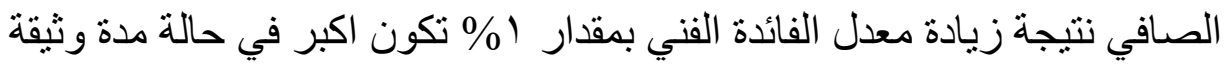

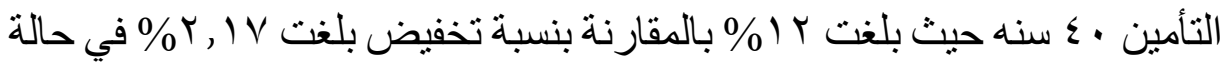

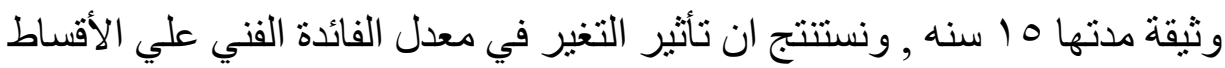
لوثيقة التأمين المؤقت ينز ايد كلما طالت مدة وثيقة التأمين لزيادة الجزء التئ الادخاري فيها .

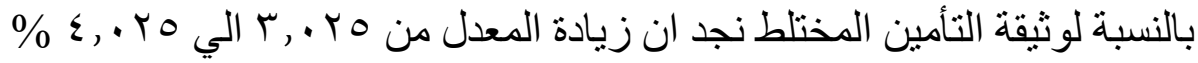

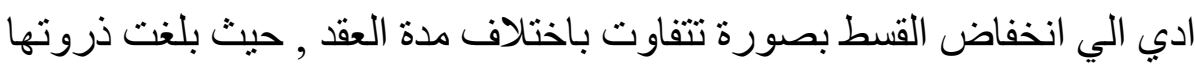

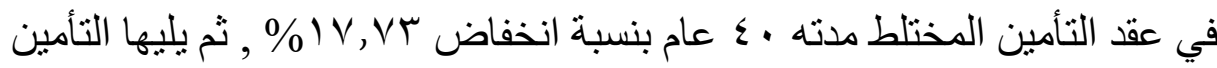

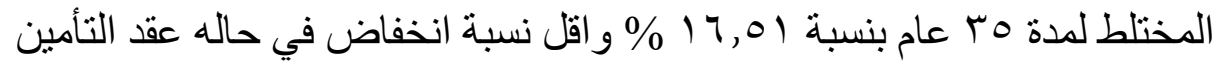

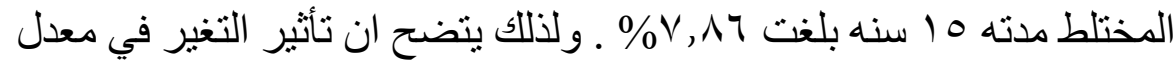

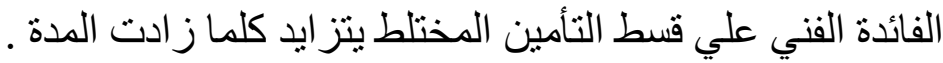

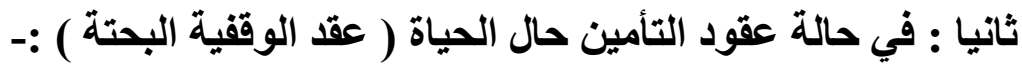

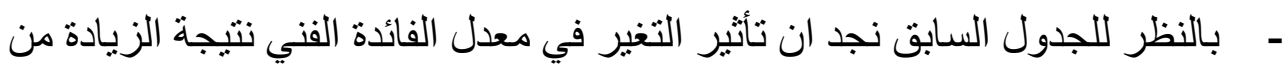

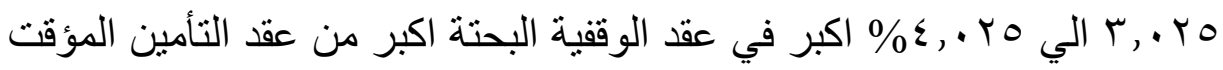
و عقد التأمين المختلط وذلك لطبيعة هذا النوع من العقود التي تغلب علئ عليها الصفة التهن

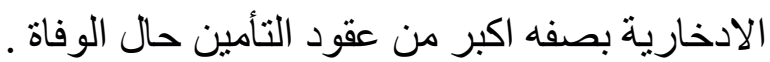

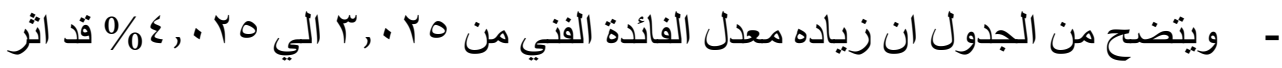

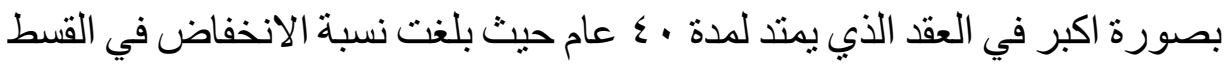

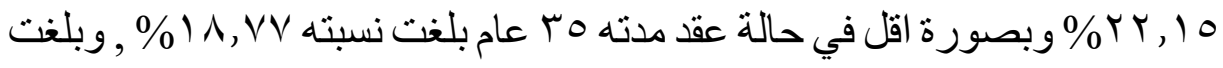

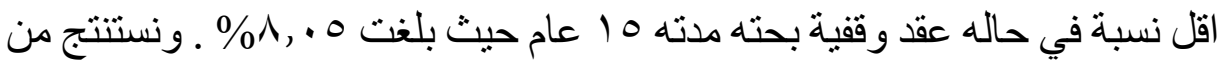

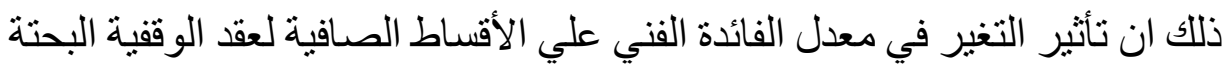

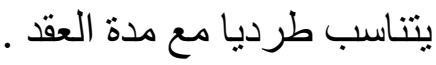
المستخلص من الجدول ان زيادة معدل الفائدة الفني علي الأقساط لكافة عقود التأمين

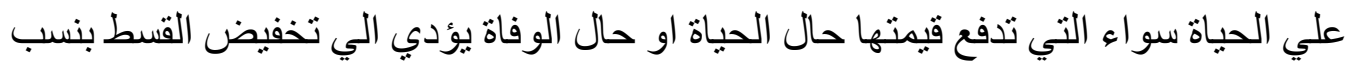
متفاوتة حسب مدة عقد التأمين 
ط/Y : تأثير تغير معدل الفائدة الفني علي عقود التأمين علي الحياة حسب نوع طريقة السداد لوثيقة التأمين . تونئ

يختلف تأثير التغير في معدل الفائدة الفني باختلاف نو عية وطريقة السداد لأقساط التأمين

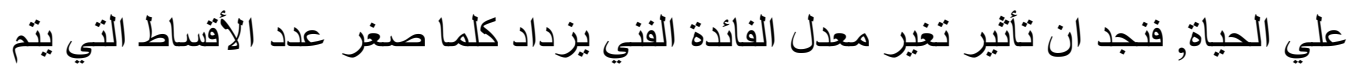

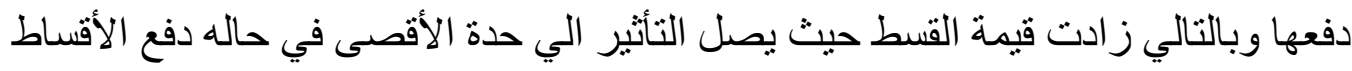

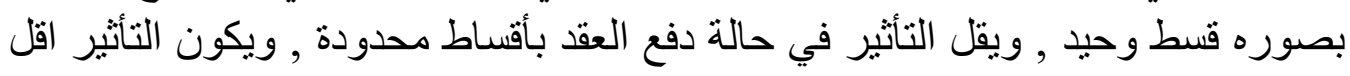

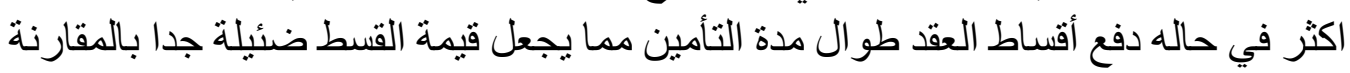

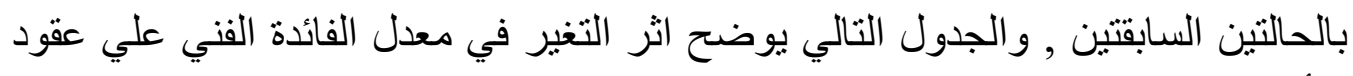
التأمين علي الحياة حسب نوع وطريقة السداد في العقود التي تدفع قيمتها حال الحياة وحال الوفاة

\section{جدول رقم (•) - (0)}

اثر التغير في معلل الفائدة الفني علي الأقساط الصافية لوثيقة تامين علي الحياة بمبلغ بلتخ

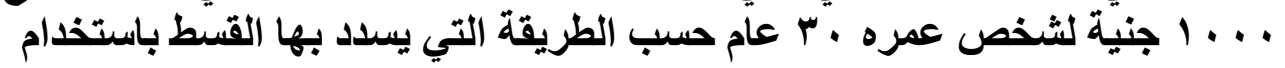
جدول (A

\begin{tabular}{|c|c|c|c|c|c|}
\hline \multirow{2}{*}{ الانخفاضبة } & \multirow{2}{*}{ القرق بين } & \multicolumn{2}{|c|}{ القسط الصافي علي أساس } & \multirow{2}{*}{ طريقة } & \multirow{2}{*}{ الوثيقة } \\
\hline & & $\% \varepsilon, \cdot$ Yo & $\% \Gamma, \cdot{ }^{\prime}$ & & \\
\hline$V, 77$ & $\cdot, r \wedge \varepsilon$ & r, $\leqslant$ Y & $r, v \cdot q$ & سنوي & \multirow{3}{*}{ لمدة · ع مام } \\
\hline$|r, r|$ & $\cdot, V 19$ & 0,177 & $0, \wedge \wedge 0$ & سنوات & \\
\hline$I V, r \wedge$ & $I Y, Y V \varepsilon$ & $0 \wedge, r_{01}$ & $V \cdot, \pi Y 0$ & قسط وحيد & \\
\hline 19,17 & $Y, Y Y \wedge$ & $q, \varepsilon \cdot r$ & $11, \pi r$. & سنوي & \multirow{3}{*}{ الحيُّة } \\
\hline$r \tau, r$. & $0,9 Y 1$ & 17,091 & $r Y, 01 Y$ & سنوات & \\
\hline$r \cdot, T \leq$ & $\Lambda T, V \backslash \Lambda$ & $1 \wedge \vee, r q \varepsilon$ & $r V \cdot, 17 r$ & قسط وحيد & \\
\hline$I \varepsilon, V V$ & $r, 1 . \tau$ & $1 V, 9 Y 9$ & $r_{1}, \cdot r_{0}$ & سنوي & مختلط \\
\hline 11,91 & סזץ, ר & $r V, \cdot \leq r$ & $r T, r \vee \wedge$ & سنوات & . لمدة عام . لمد \\
\hline
\end{tabular}




\begin{tabular}{|c|c|c|c|c|c|}
\hline$r M, \wedge r$ & $90, \leqslant \leqslant 9$ & $r .0,1\} q$ & $\varepsilon \ldots, 0 \vee \wedge$ & قسط وحيد & \\
\hline 19,11 & r, & $9,9 \leq \leq$ & I & سنوي & وقفية \\
\hline$r Y, V O$ & $\Gamma, \wedge \wedge$ & $1 \Gamma, 1 \vee V$ & $1 \mathrm{~V}, .0 \mathrm{~V}$ & سنو ات 10 & لمدة \\
\hline$r \wedge, 7 \varepsilon$ & VY, & IA.,TY & ror, TVq & قسط وحيد & هץ عام \\
\hline
\end{tabular}

يتضح من الجدول السابق الاتي :-

أولا: بالنسبة لعقود التأمين التي تدفع قيمتها حال الوفاة :-

- بالنسبة لوثيقة التأمين المؤقت لمدة · ب عام:

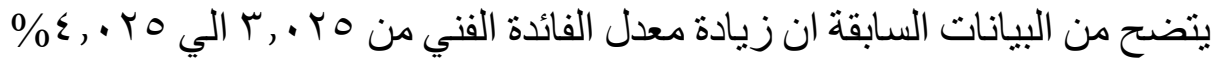

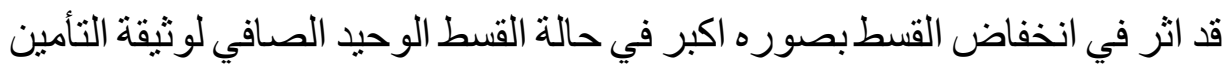

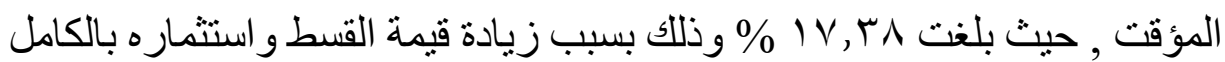

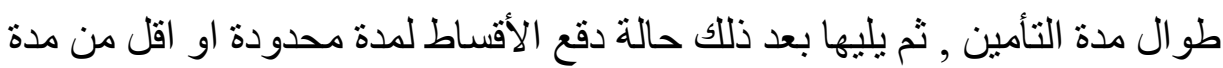

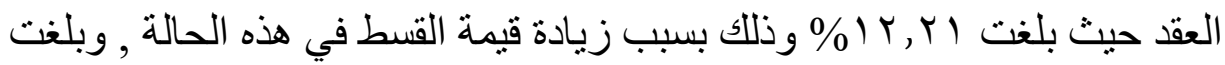

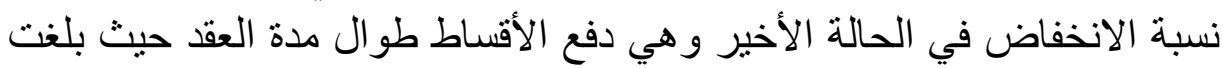

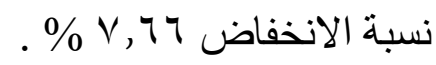
بالنسبة لوثيقة التأمين مدي الحياة :

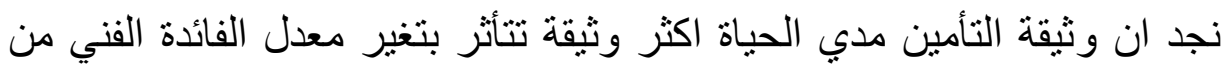

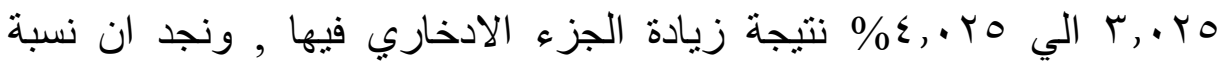

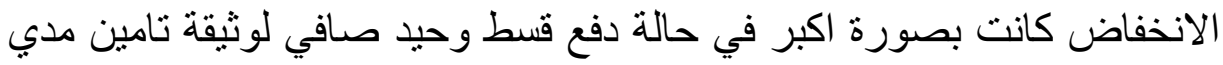

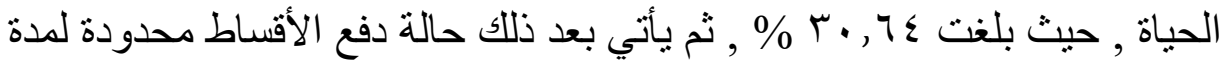

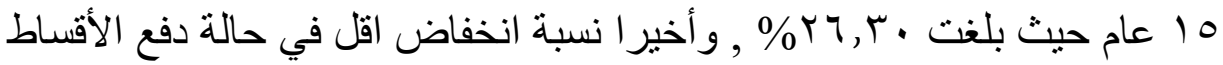

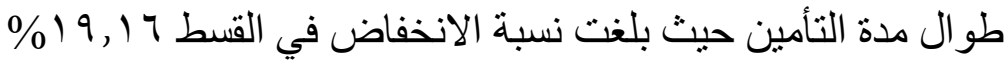

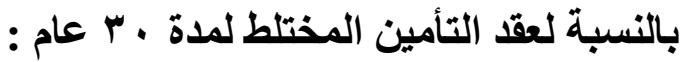

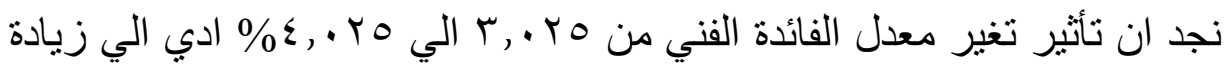

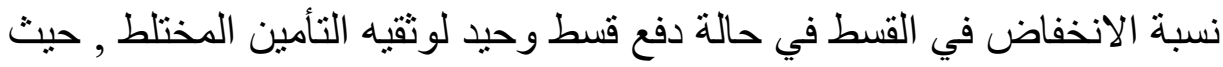

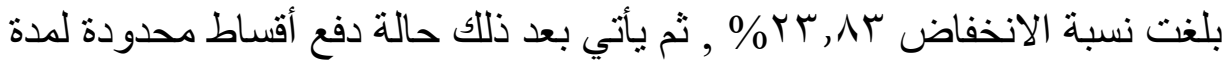

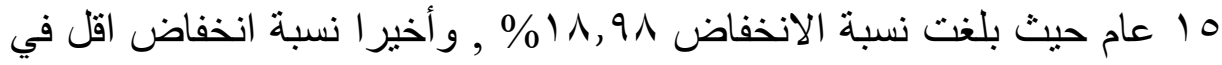


حالة دفع أقساط الوثيقة بصوره سنوية طو ال مدة العقد حيث بلغت نسبة الانخفاض $\%) \varepsilon, V V$

\section{ثثانيا : العقود التي تدفع قيمتها حال الحياة :}

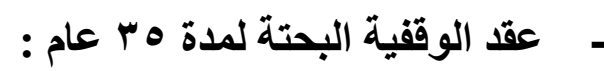

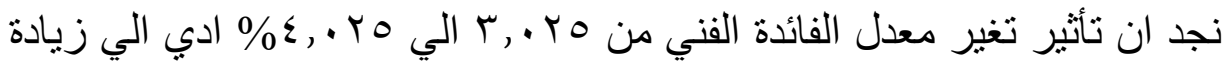

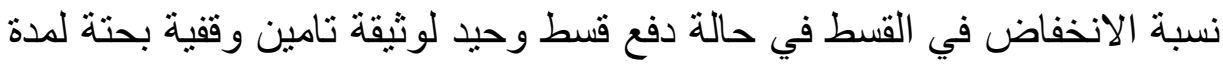

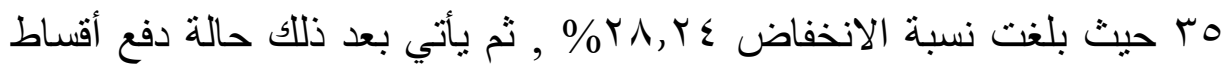

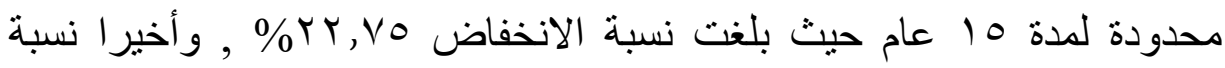

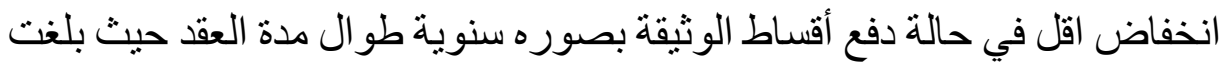

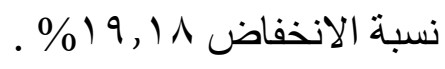

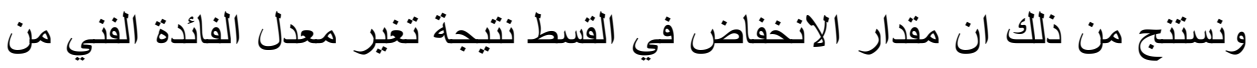

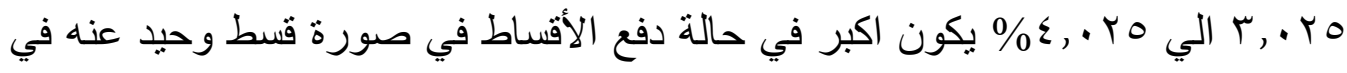

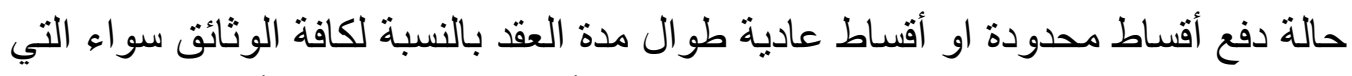

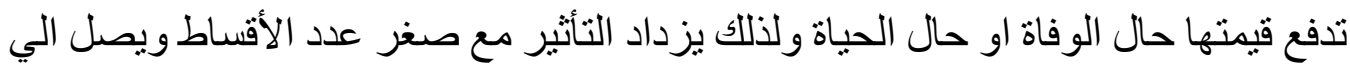

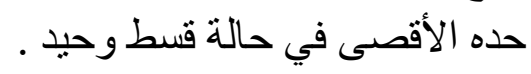

ع/T : تأثير تغير معدل الفائدة الفني علي عقود التأمين علي الحياة حسب سن المؤمن عليه عند الإصدار . المعرل

يختلف تأثثر تغير معدل الفائدة الفني علي أقساط عقود التأمين علي الحياة حسب سن المؤمن

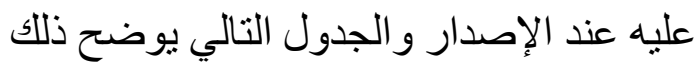

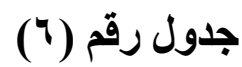

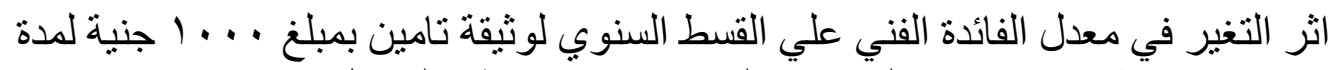

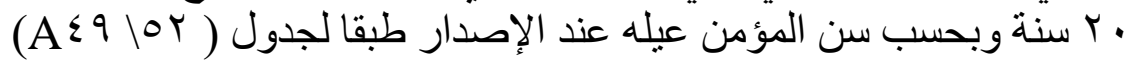




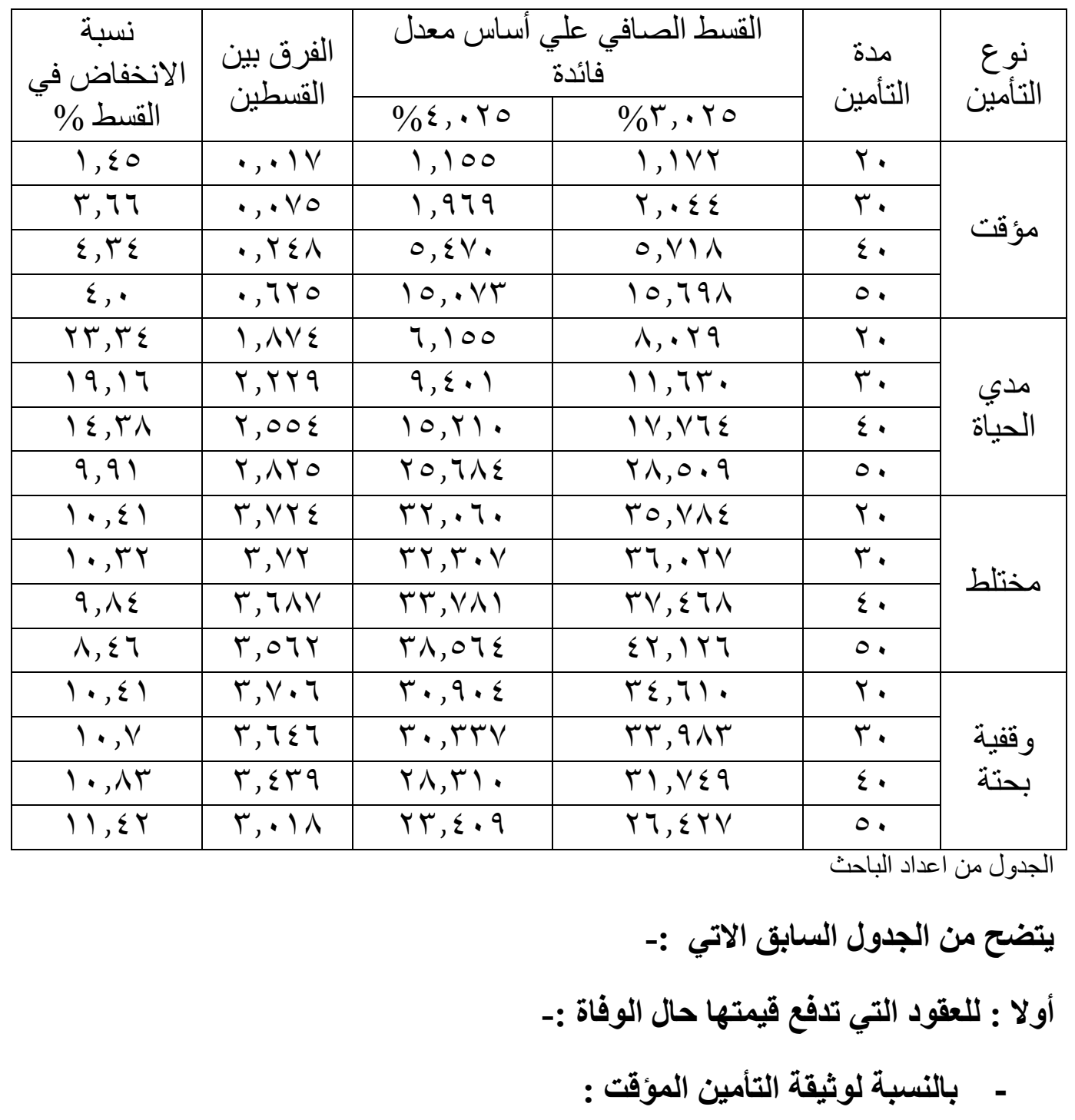




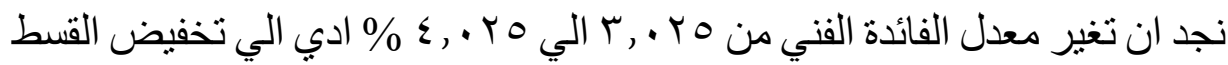

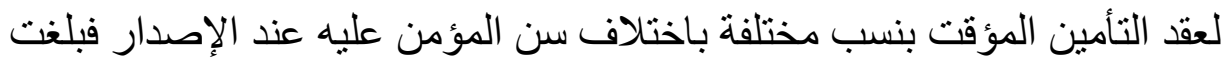

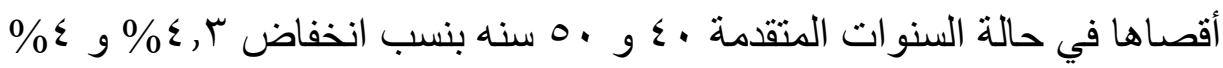

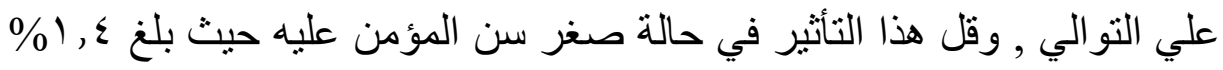

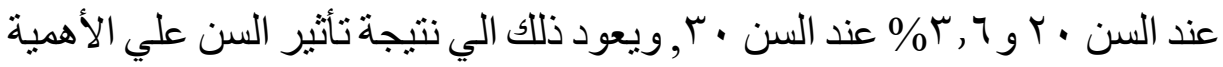

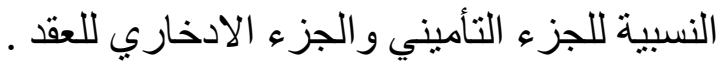

\section{بالنسبة لعقد التأمين مدي الحياة :}

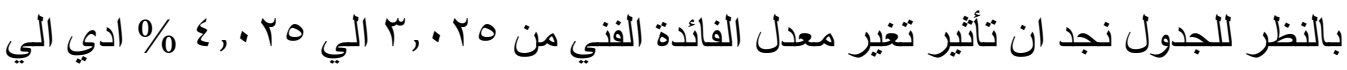

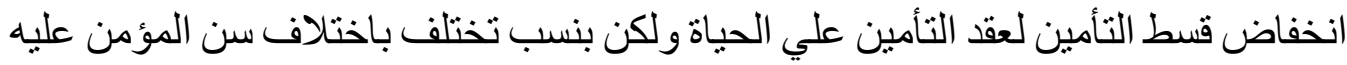

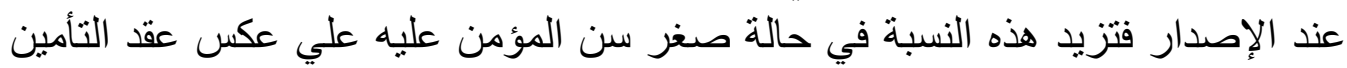

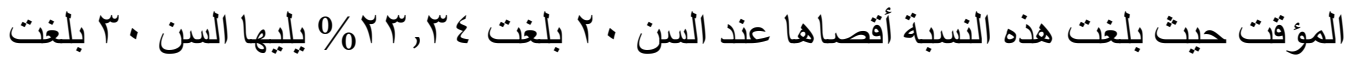

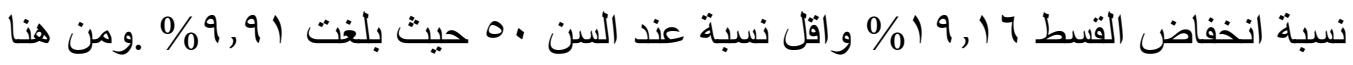

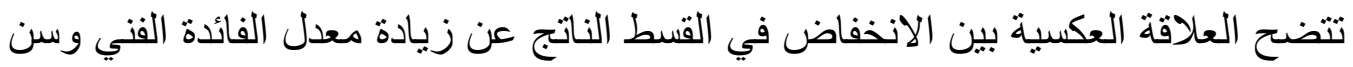
المؤمن عليه عند الإصدار في عقد التأمين مدي الحياة .

\section{- بالنسبة لعقد التأمين المختلط :}

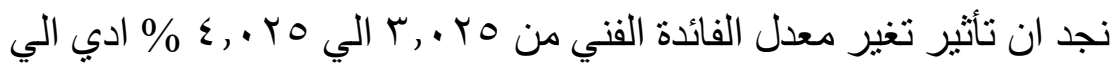
انخفاض قسط التأمين لعقد المختلط ولكن بنسب تختلف بنان باختلاف سن المؤمن عليه

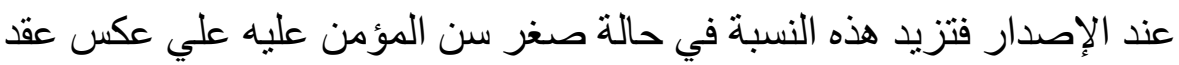

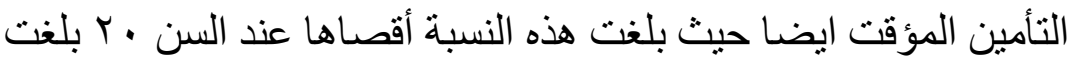

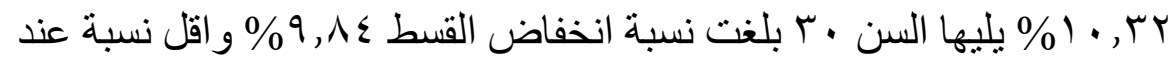

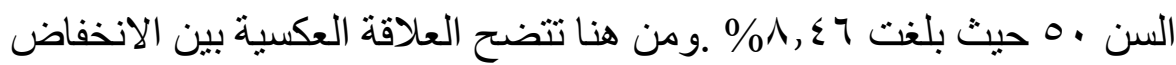

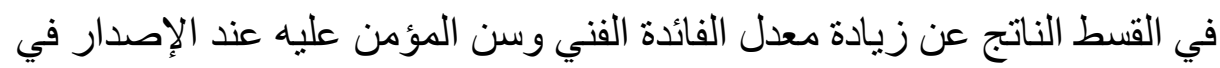

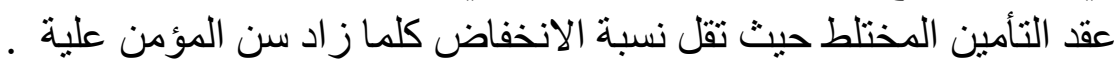

ثانيا : العقود التي تدفع قيمتها حال الحياة : -

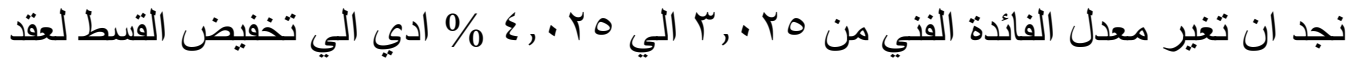

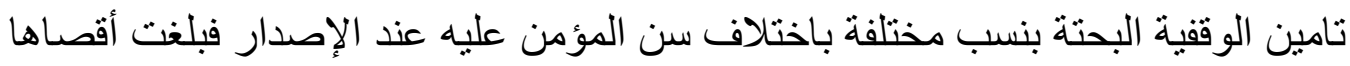

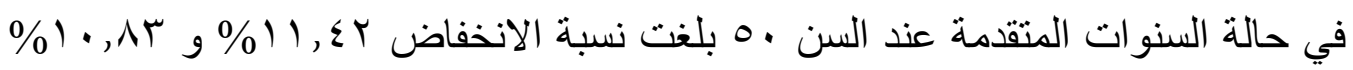




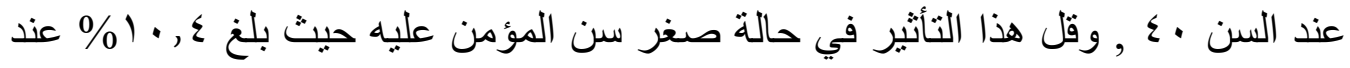

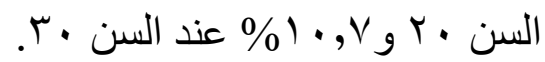

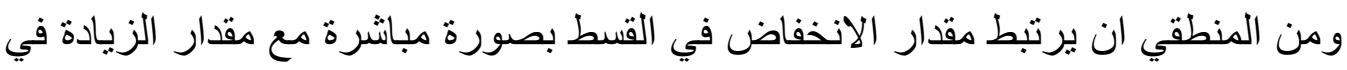

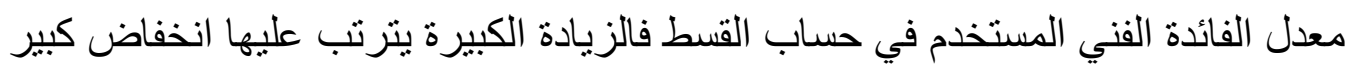
في مقدار القسط . معذاندة الفي

\section{ץ/ه : تقيم معدل الفائدة القني المستخدم في حساب الأقساط الصافية لعقود}

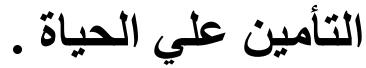

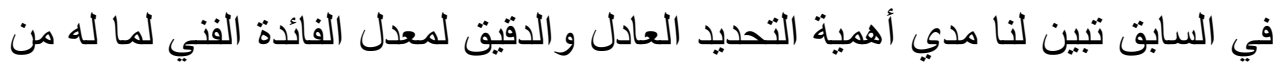

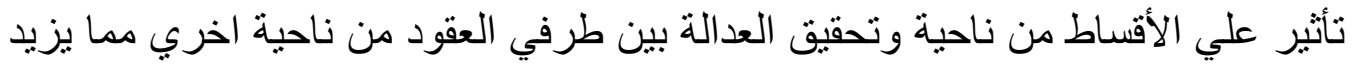

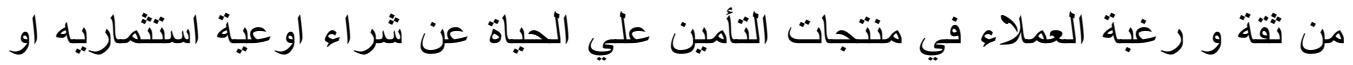
ادخارية اخري بالبنوك ك.

\section{أن منتجات التأمين علي الحياة يجب ان تعمل علي تحقيق هدفين للعملاء '”-}

• الهدف الأول هو أن عملاء التأمين يريدون الحماية من العواقب المالية السلبية

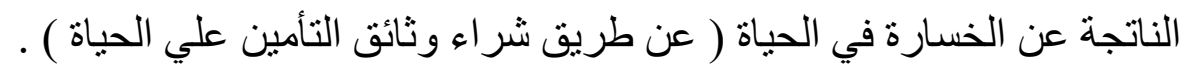

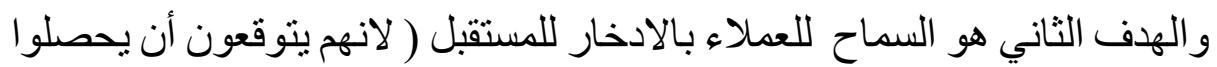

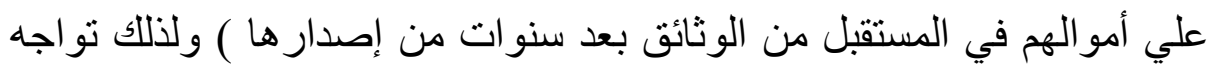

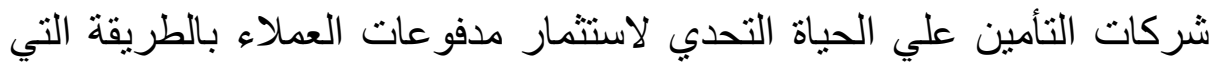

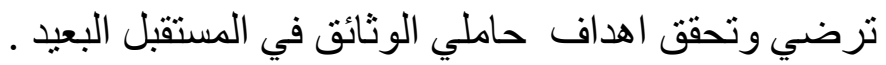

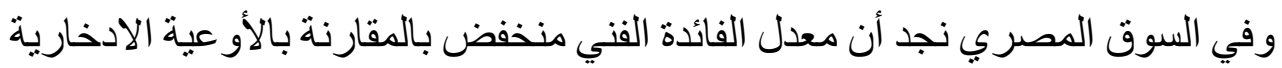
الأخرى او معدلات استثمار شركات التأمين في السوق بشكل الفئ عام حيث يبلغ معدل الفائدة

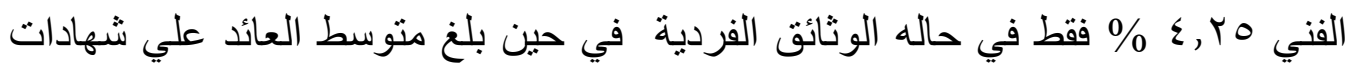

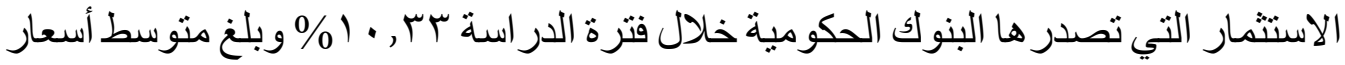

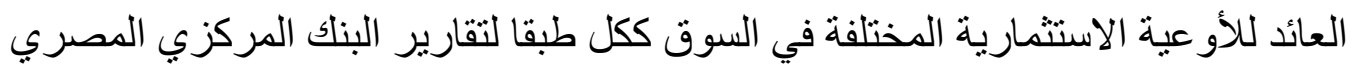

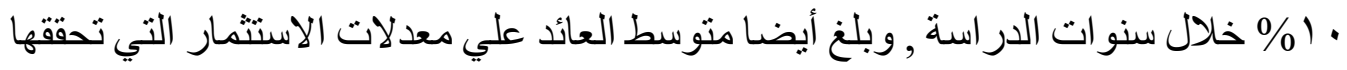

'. Berends, K., McMenamin, R., Plestis, T., \& Rosen, R. J. ( $(\cdot 1 r)$. The sensitivity of life insurance firms to interest rate changes. Economic Perspectives, $r^{r}(r)$. 
شركات التأمين السوق الدصري خلال سنوات الدراسة ه, • 1 \% ـ ـ ويؤدي وجود الفرق

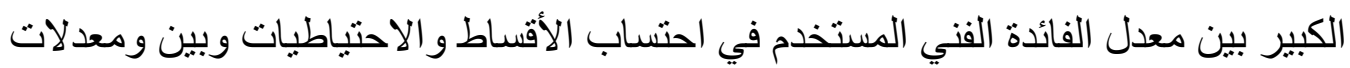

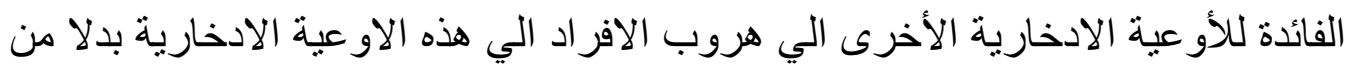

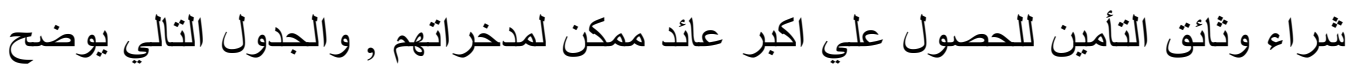

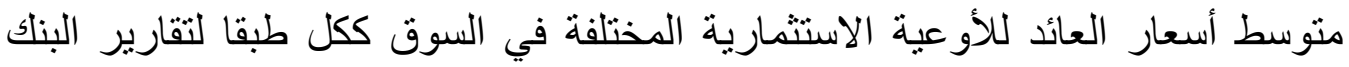

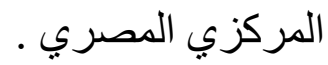

\section{جدول رقم (V)}

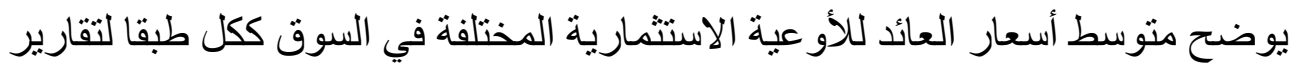

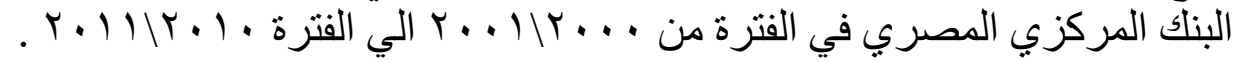

\begin{tabular}{|c|c|c|c|c|c|c|}
\hline المتوسط العام & توفي صند العائدة & شعائد & سلي الذّز التعائد & مثل معر الفائدة الودائع & سعر الفائدة متوسط & السنوات \\
\hline $11, r$ & 11,0 & Ir & $9, \cdot 9$ & 9,0 & $1 T, \leq \varepsilon$ & $r \ldots l / r \ldots$ \\
\hline $1 \cdot, \times 7$ & 11,0 & 11,0 & $\vee, \vee q$ & $9,7 \leq$ & qr, & $r \ldots r / r \ldots l$ \\
\hline ع ז, & $1 \cdot, 0$ & $1 \cdot, 0$ & ו ו, & 1,79 & IT,V & $r \ldots r / r \ldots r$ \\
\hline $1 \cdot, 10$ & $1 \cdot, 0$ & $1 \cdot, 0$ & $\Lambda, \varepsilon 1$ & $V, 97$ & $1 T, \varepsilon$ & $r \ldots \varepsilon / r \ldots r$ \\
\hline 1. & $1 \cdot, 0$ & $1 \cdot, 0$ & $1 \cdot, 1 r$ & $V, 77$ & q & $r \ldots o / r \ldots \varepsilon$ \\
\hline$q, \leqslant 1 r$ & 9,0 & 9,0 & $\Lambda, \Lambda r$ & 7,01 & $|r, V|$ & $r \ldots T / r \ldots 0$ \\
\hline q, & 9,0 & 1 . & 1,70 & $7, \cdot 1$ & $1\}, 7 \varepsilon$ & $r \ldots r / r \ldots r$ \\
\hline 1,907 & 9,0 & 1 . & $7,9 V$ & 7,9 & $I r, Y r$ & $r \ldots \Lambda / r \cdot r$ \\
\hline 1 . & $q, r V$ & 1 . & זr, & $V, \cdot r$ & Ir, & $r \ldots q / r \ldots 1$ \\
\hline $9,10 r$ & 9 & 9,01 & 9,17 & $0,9 V$ & هـ, 11 & $r \cdot 1 \cdot / r \cdot . q$ \\
\hline$q, r \mid r$ & 9 & $9,0$. & $1 \cdot, r$. & $7, O Y$ & $1 \cdot, \wedge \varepsilon$ & $r \cdot 1 \cdot / r \cdot 11$ \\
\hline 9,19 & $1 \cdot, \cdot r$ & سז, • & 9,0 & V, MN & $1 r, 71$ & المتوسط العام \\
\hline
\end{tabular}

الجدول من اعداد الباحث من خلال الكتاب الاحصائي اعداد مختلفة يتضح من الجدول السابق الاتي :- 
- بالنظر الي الجدول السابق معدل الفائدة الفني منخفض بالمقارنة بالأو عية الادخارية

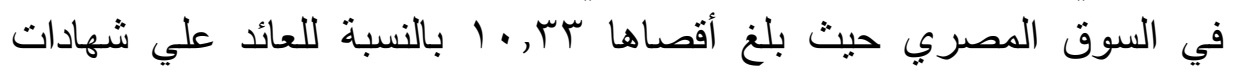

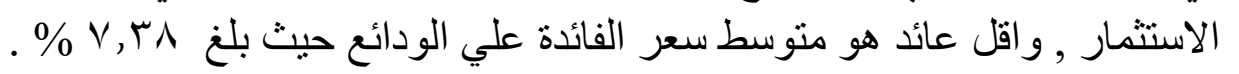

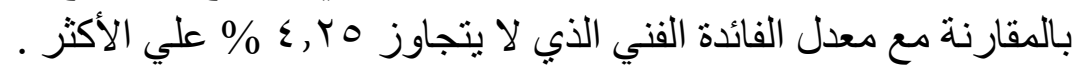

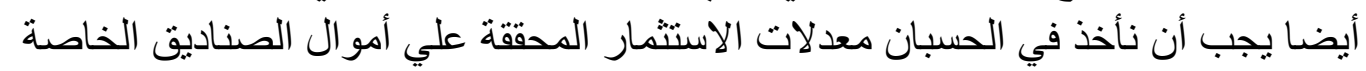

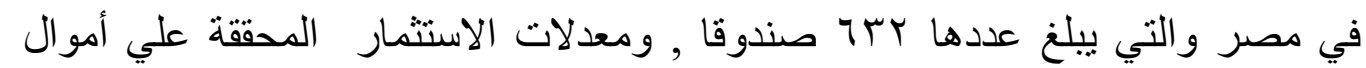

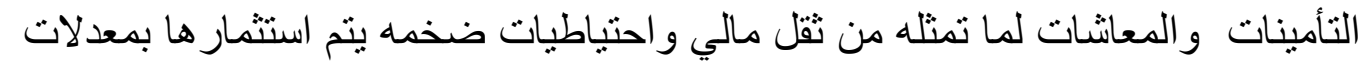

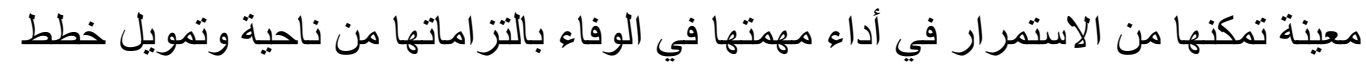

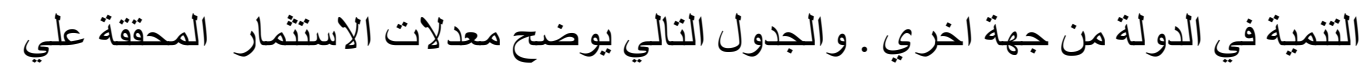

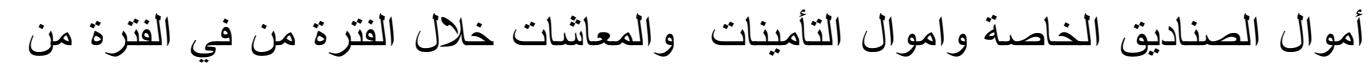

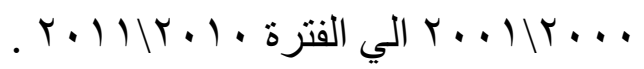

\section{جدول رقم (^) - (^)}

و والجدول يوضح معدلات الاستثمار الصناديق الخاصة و وصندوقي التأمينات

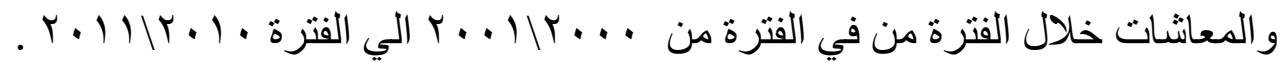

\begin{tabular}{|c|c|c|c|}
\hline 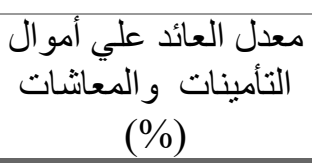 & 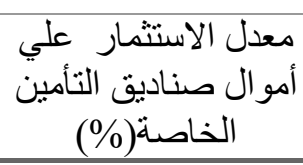 & حمدلة الستثمار امو ال & 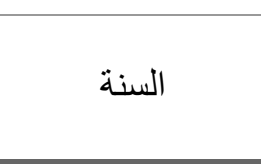 \\
\hline 1 & $11, r$ & $1 \cdot, 109$ & $r \ldots l / r \ldots$ \\
\hline 1. & $11, \pi$ & $\Lambda, \wedge Y$ & $r \ldots r / r \ldots l$ \\
\hline 1. & $1 \cdot, 0 \mathrm{~V}$ & 9,11 & $r \ldots r / r \ldots r$ \\
\hline 9 & $1 \cdot, \lambda 1$ & $11, r$ & $r \ldots \varepsilon / r \ldots r$ \\
\hline 9 & $1 \cdot, \wedge$ & $1 \cdot, Y_{T}$ & $r \ldots / r \ldots \varepsilon$ \\
\hline 9 & $1 \cdot, \varepsilon$ & 11,97 & $r \ldots T / r \ldots o$ \\
\hline 9 & 11 & $11, \mathrm{~V}$ & $r \ldots V / r \ldots T$ \\
\hline$\Lambda$ & $1 \cdot, V$ & $9,0 Y$ & $r \ldots \lambda / r \ldots v$ \\
\hline$\wedge$ & $1 \cdot, 9$ & $11, r$ & $r \ldots q / r \ldots 1$ \\
\hline$\Lambda$ & $1 \cdot, 7$ & $1 \cdot, 1$ & $r \cdot 1 \cdot / r \cdot . q$ \\
\hline
\end{tabular}




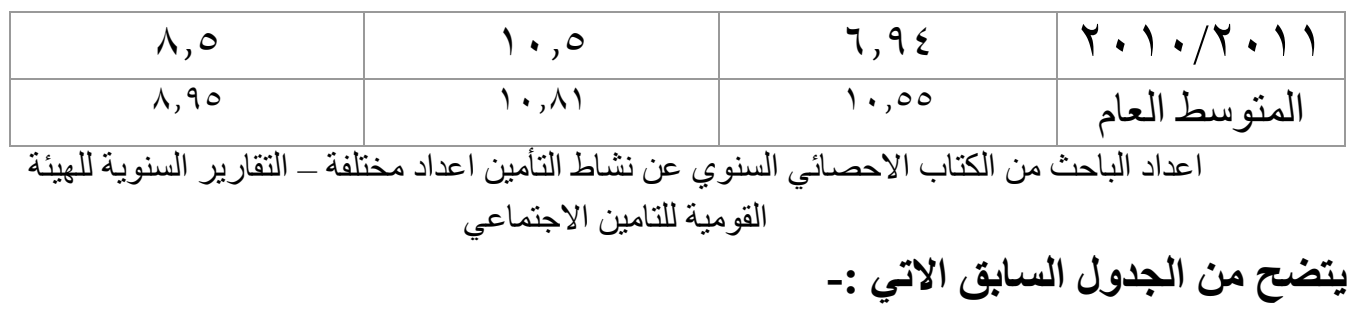

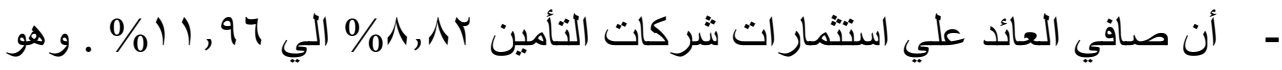

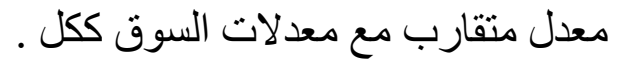

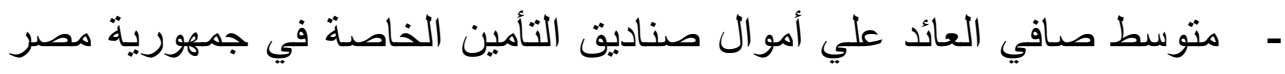

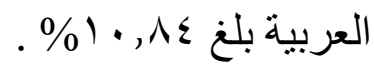
- متوسط العو ائد علي استثمار هات أمو ال صناديق التأمين الاجتماعي العام و الخاص $\% 9,9$

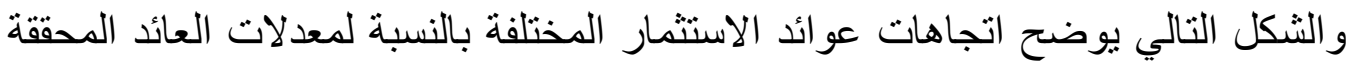

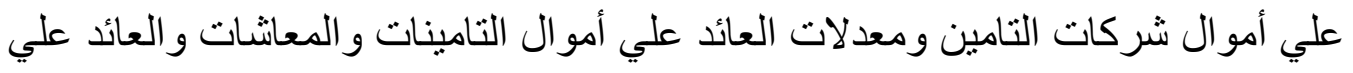

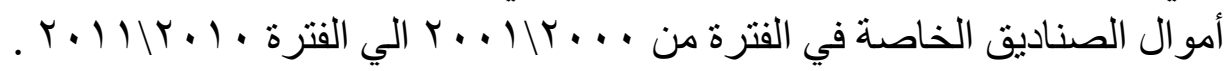

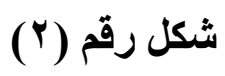

اتجاهات معدلات الاستثمار المختلفة 


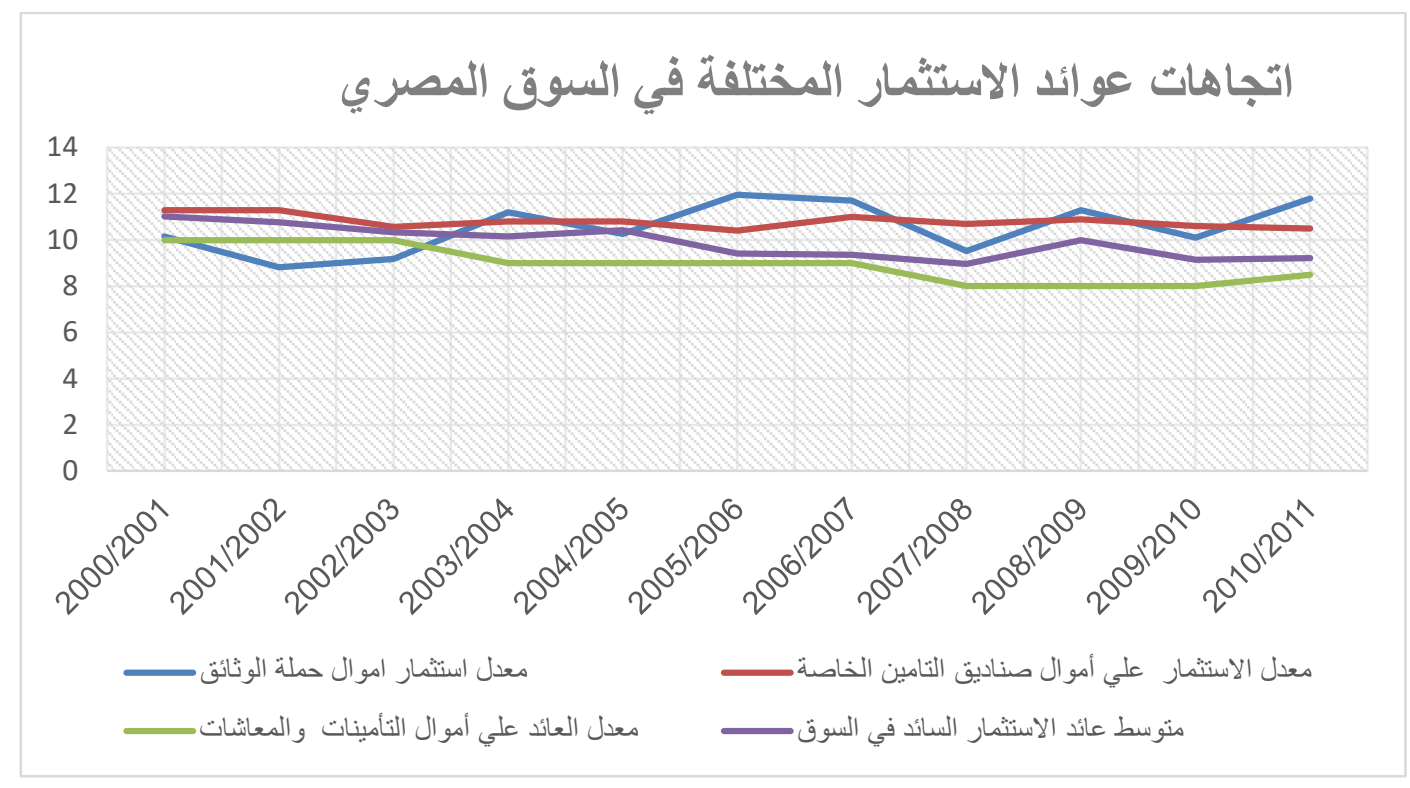

$$
\text { الثكل من اعداد الباحث من خلال استخدام بر امج الحاسب الالي }
$$

و ون الشكل السابق يتضح أنه رغم تذبذب العو ائد المحققة سو اء عائد أمو ال شركات التامين علي الحياة او أمو ال التأمينات و المعاثات او أمو ال الصناديق الخاصة الثاب الا أنها متقاربة فيما بينها , ويجب أن يتناسب معدل الفائدة الفني مع هذه المعدلات نظر الأنها تقدم خدمات تأمينية متقاربة .

ونجد أن معدل الفائدة الفني يختلف من وثيقة الي اخري غير ثابت في كل الوثائق حسب المزايا التي تقدمها كل وثيقة حيث نجد أن معدل الفائدة الفني المستخدم في حساب أقداط أنساط وثائق التأمين المشتركة بالأرباح اقل من معدل الفائدة الفني المستخدم في حساب الوثائق

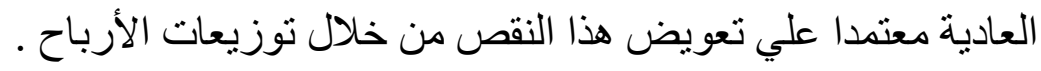

ويتضح مما سبق ضرورة رفع معدل الفائدة الفني الذي تستخدمه شركات التأمين علي الحياة في تحديد أقساط الوثائق التي تصدر ها حتي يتناسب مع اتجاهات عو ائد الاستثمار السائدة في السوق , و المعدلات الفنية المستخدمة في صناديق التأمين الخاصة و نظم التأمينات التئي

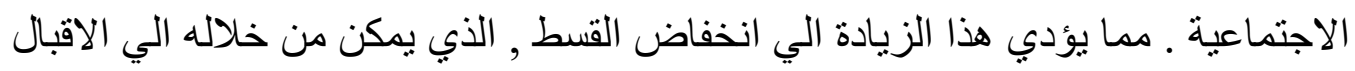

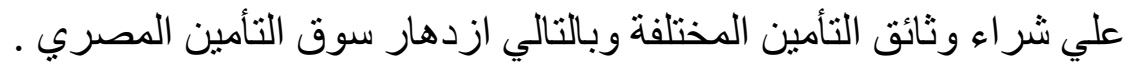


في الجزء السابق تناولنا مفهوم معدل الفائدة الفني و أهميته في تحديد أقساط التأمين علي

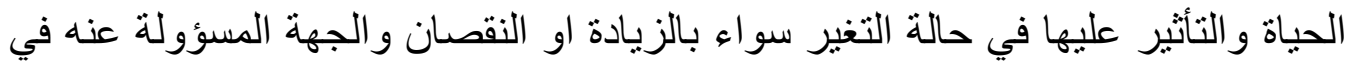

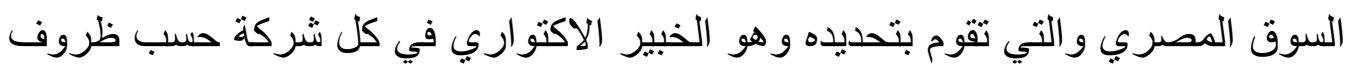

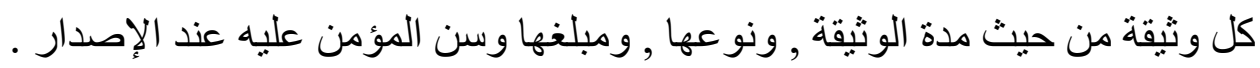

\section{7 ا ج مقارنة معدل الفائدة الفني في السوق المصري بالمعدلات الفنية في السوق}

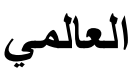

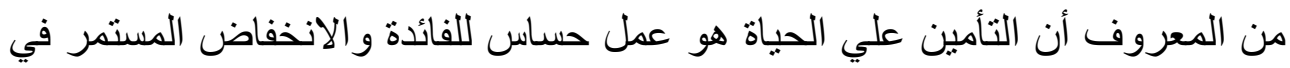

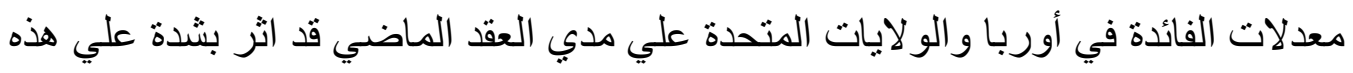

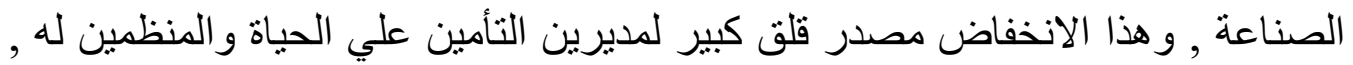

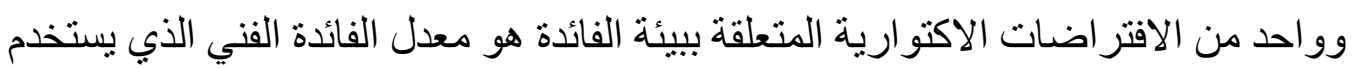

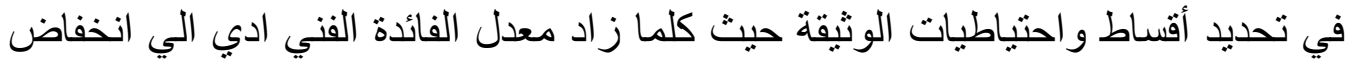

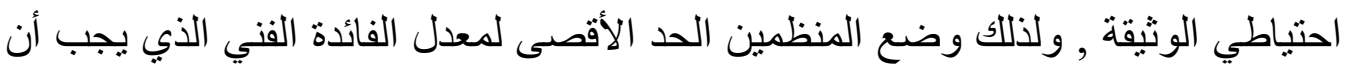

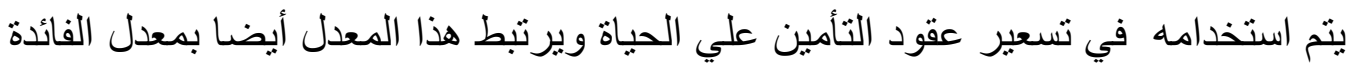

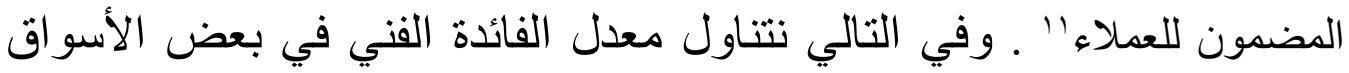
العالمية

\section{1/1/ : معدل الفائدة القني في سوق التأمين الألماني .}

ادي أنشاء سوق تامين اوربي مشترك داخل الاتحاد الأوربي الي خضوع سوق التأمين

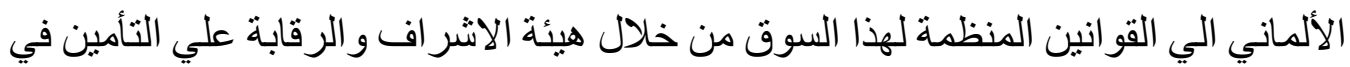

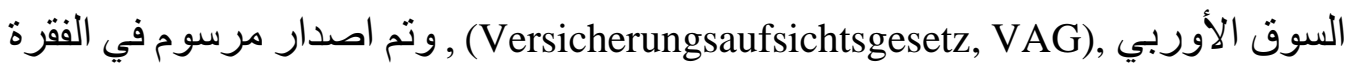
70 من قانون الاشر اف و الرقابة بتحديد الحد الأقصى لمعدل الفائدة الفني في عقود التأمين علي الحياة وذلك عن من خلانل طريقتين :

\footnotetext{
"Eling, M., \& Holder, S. Maximum technical interest rates in life insurance in Europe and the United States: An overview and comparison. The Geneva Papers on Risk and Insurance-Issues and Practice, rN(r),pr
} 


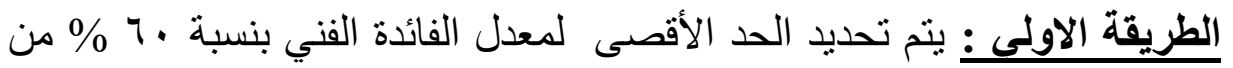

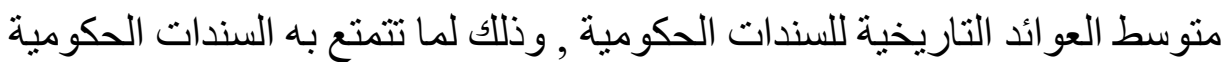

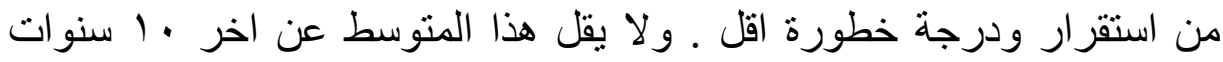

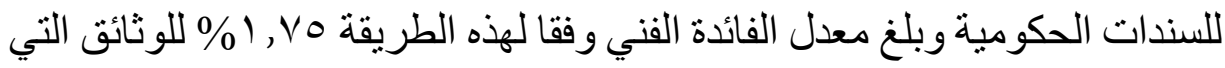

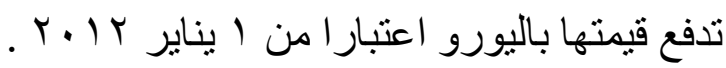

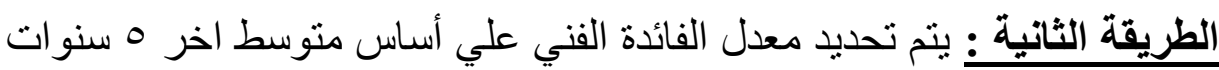

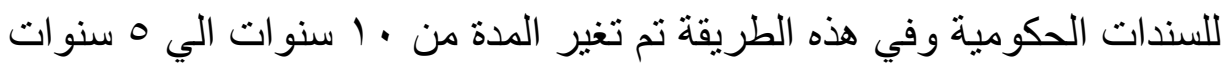

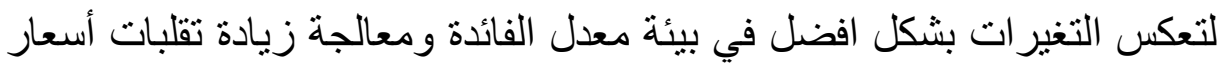

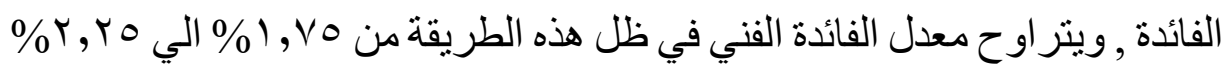

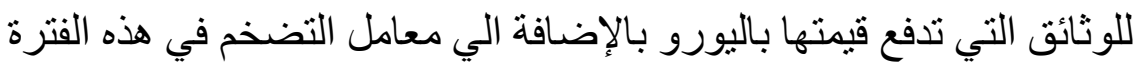

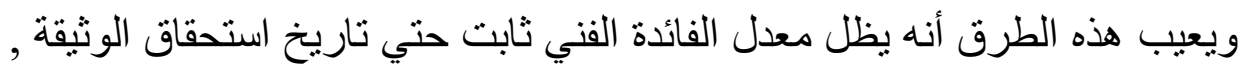

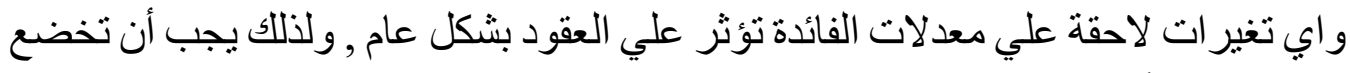

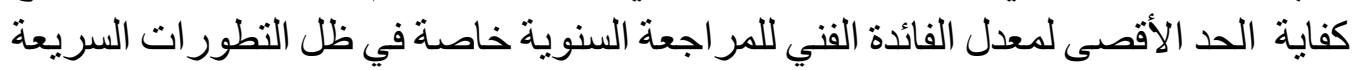

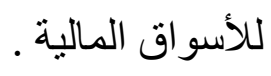

\section{צ/ץ : معدل الفائدة الفني في بسوق التأمين النمساوي .}

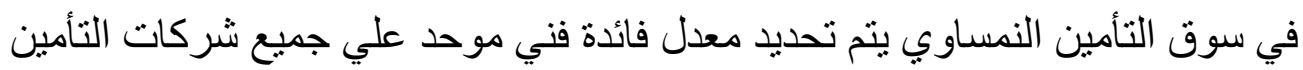

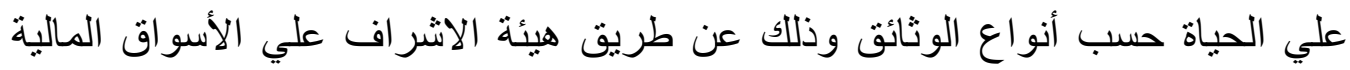

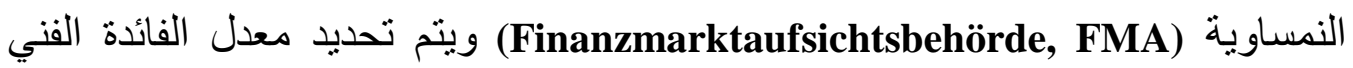
كقيمة ثابتة ( مع احتمالية التغير خلال سنو ات الوثيقة ) حسب التغير ات في الأسو اق المالية

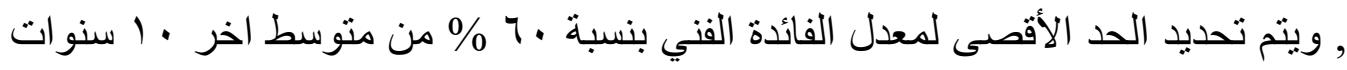

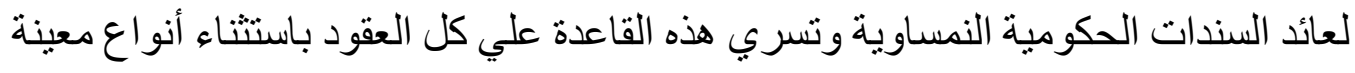

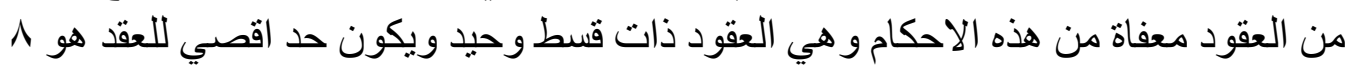

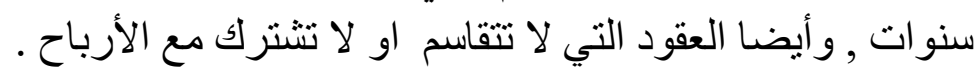

\section{r/r/ : معدل الفائدة الفني في بسوق التأمين السويسري .}

علي الرغم أن سويسرا ليست عضوه في التحالفات الاقتصادية الأوربية , الا أن

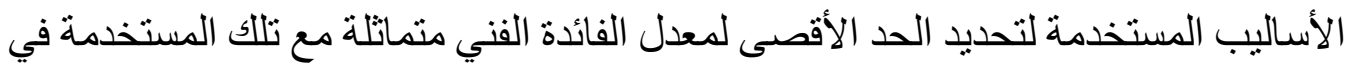


(Aufsichtsverordnung, AVO). المانيا و النمسا , ويقوم مجلس الاتحاد السويسري (AVO)

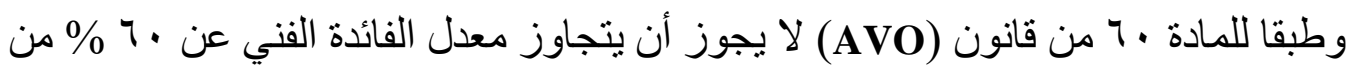

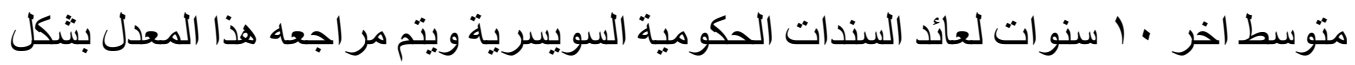

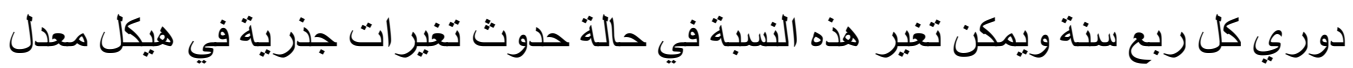

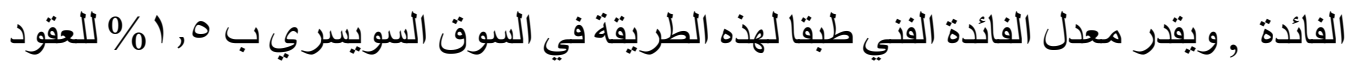

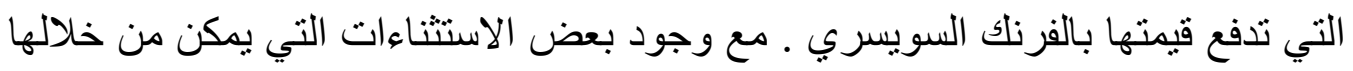

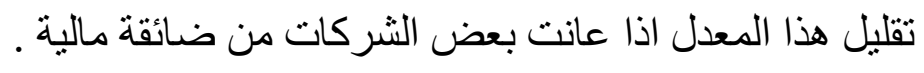

\section{4اء؛ : معدل الفائدة الفني في سوق التأمين بالولايات المتحدة الامريكية .}

بموجب قانون (McCarran-Ferguson Act) عام 9 ؛ 9 القع معظم أنظمة التأمين تحت

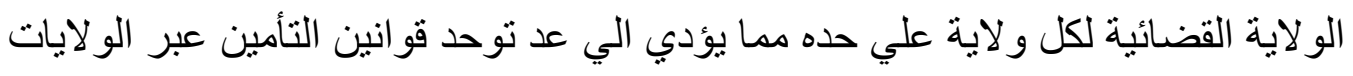

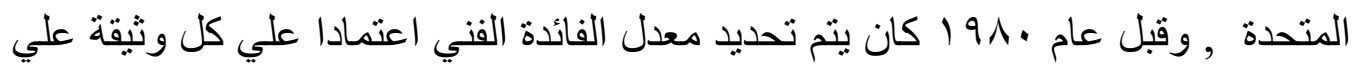

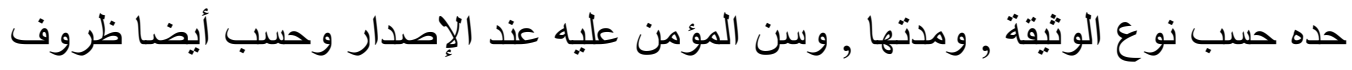

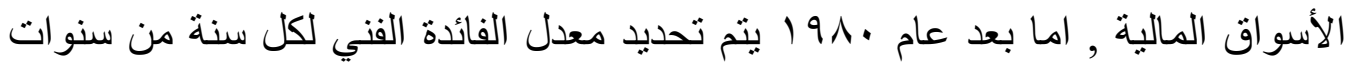

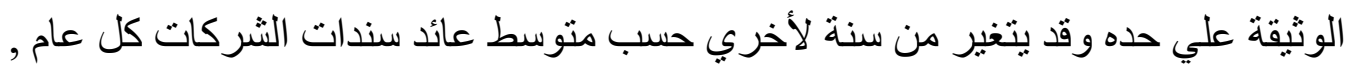

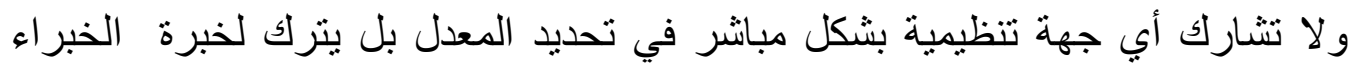

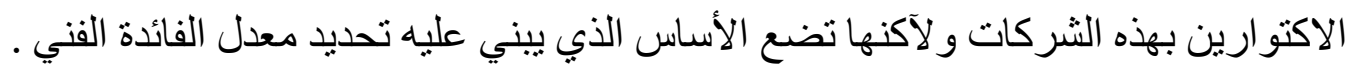

\section{// آ : معدل الفائدة القني في سوق التأمين بالمملكة المتحدة}

علي عكس الدول الأعضاء في المجمو عة الاقتصادية الأوربية ـ نجد أن المملكة المتحدة

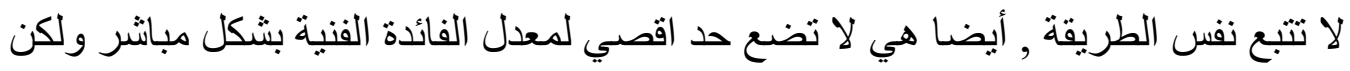

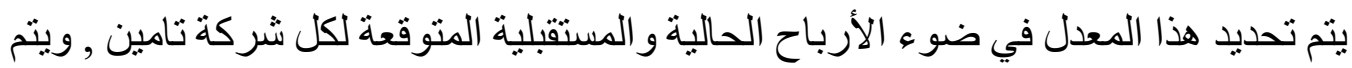

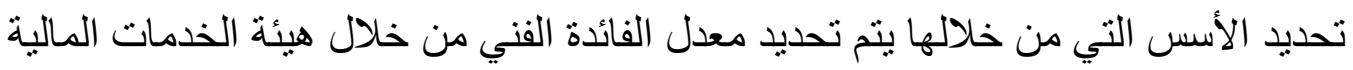
(Financial Services Authority (FSA) )

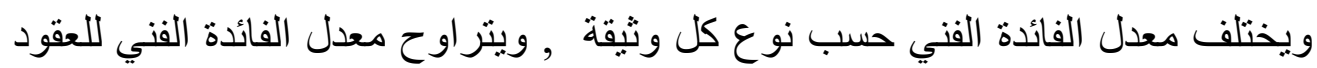

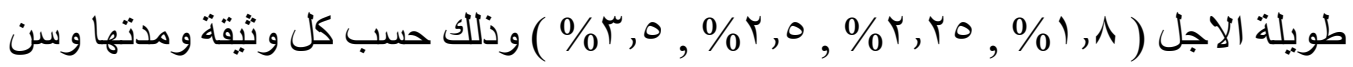

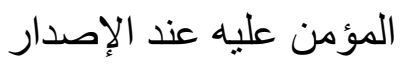




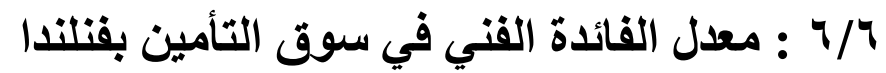

في نظام التقاعد الوظيفي الفنلندي جميع مؤســســات التقاعد لديها معدل الفائدة الفني

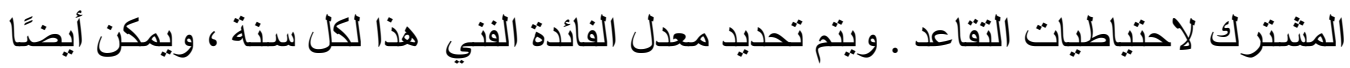

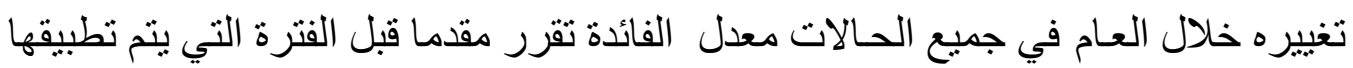

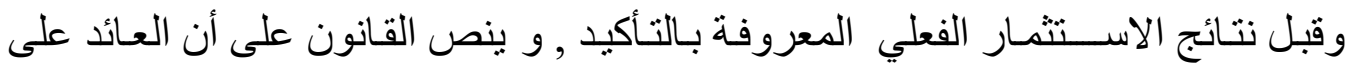

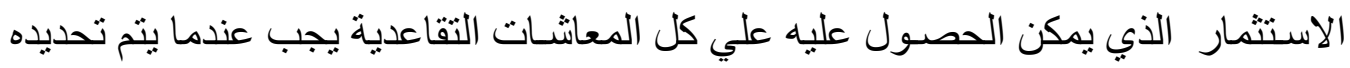

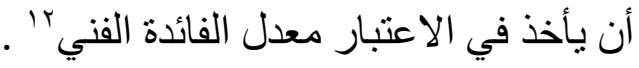

ويتم تحديد "معدل الفائدة الفني" في فلندا عن طريق إيجاد الحد الأقصى للعائد علي

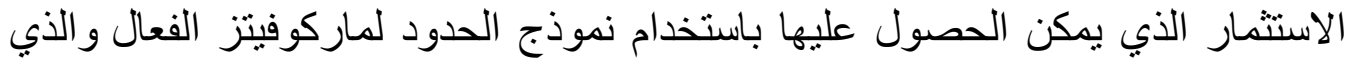

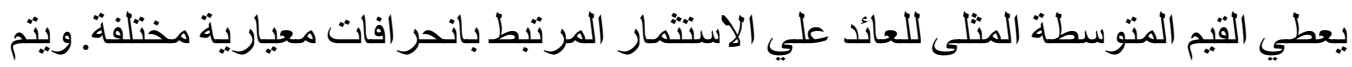

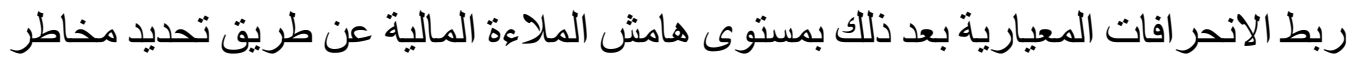

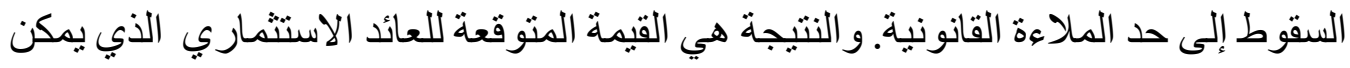

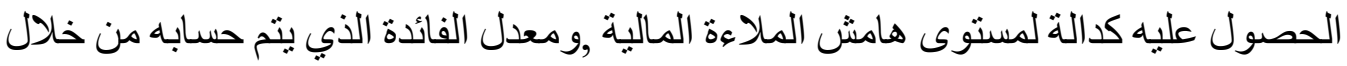

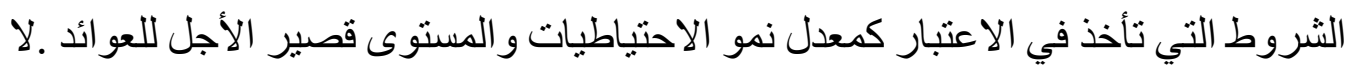

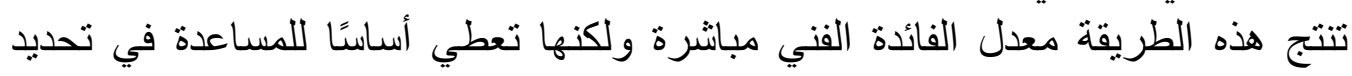
المستوى المناسب لمعدل الفائدة.

بالنظر الي بعض أسواق التأمين العالمية التي تم ذكرها في السابق ومقارنة بينها وبين

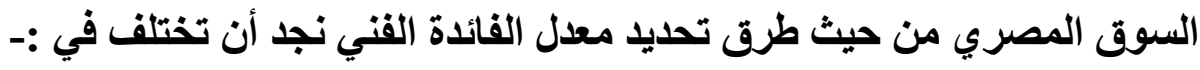

أن تحديد معدل الفائدة الفني يتم من خلال جهات تتظيمية بهذه الدول وتلزم الثركات الأل الفات

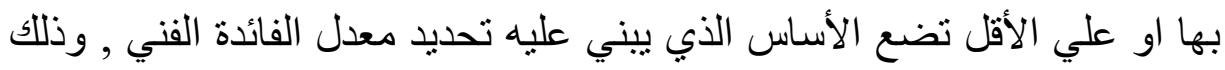

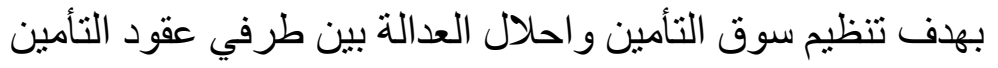

\footnotetext{
"'Ranne, A., Kivisaari, E., \& Mannonen, H. ( . . . J June). Determining the Technical Interest Rate in the Finnish Employment Pension Scheme. In Transactions of the $1 \cdot$ th International AFIR Colloquium, Tromso.
} 
اغلب هذه الأسو اق وضعت أسس معينة وثابتة لتحديد معدل الفائدة الفني وتم ربط

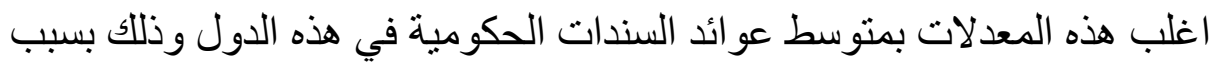

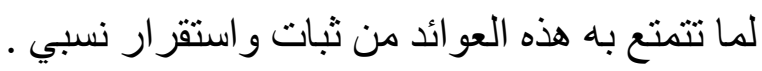

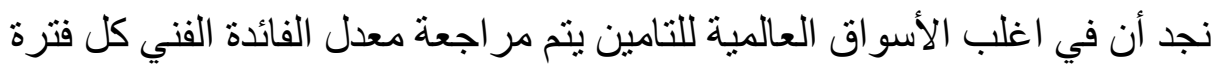

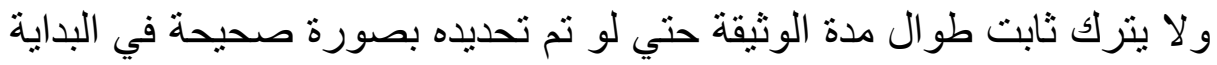

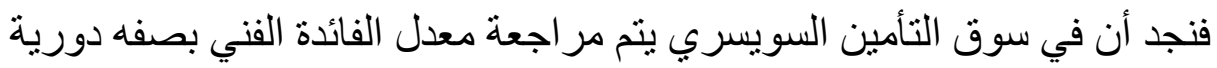

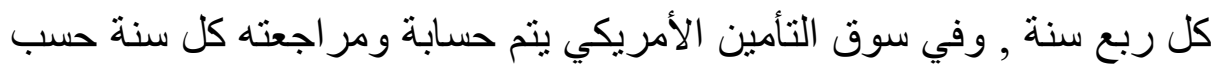

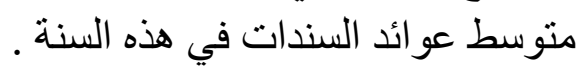

النتائج و التوصيات

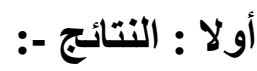

1 - توجد علاقة عكسية بين معدل الفائدة الفني الذي يستخدم في حساب الأقساط

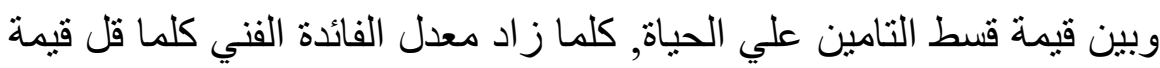
قسط التامين علي الحياة

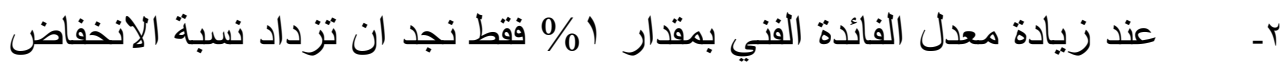

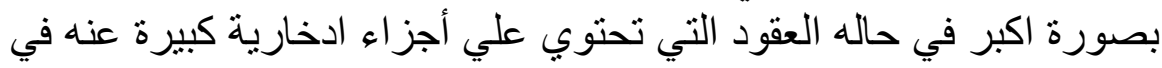

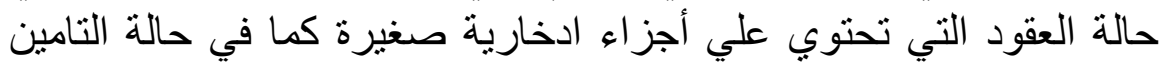

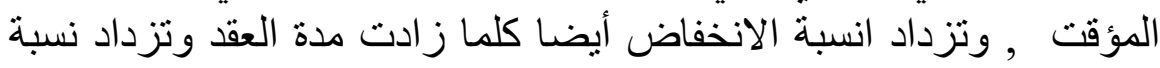

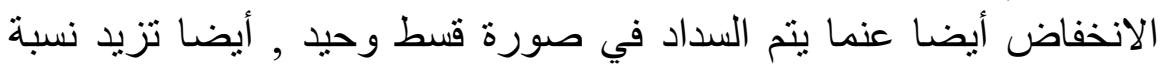

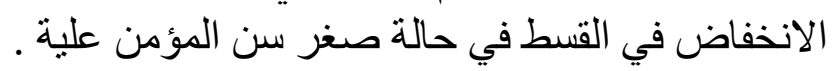

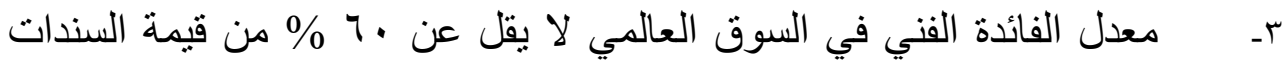

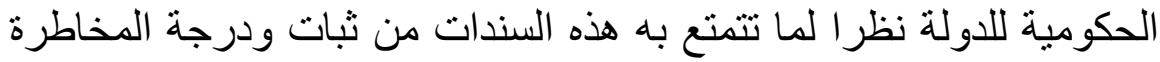

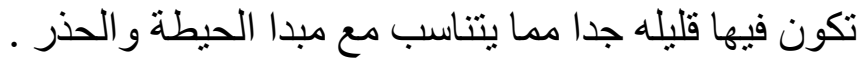

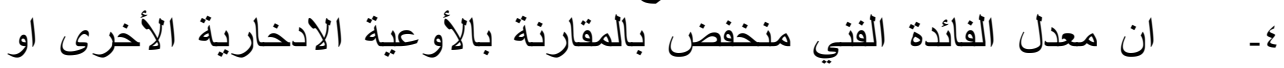

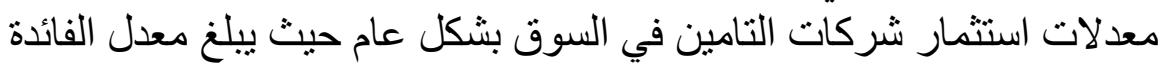

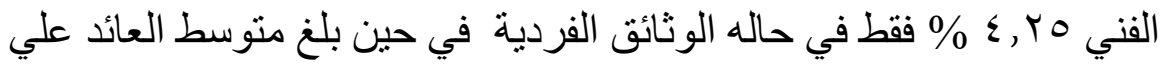

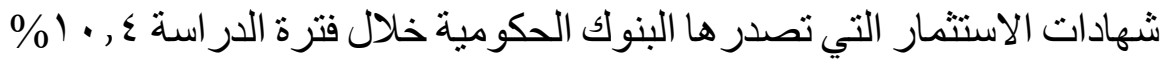

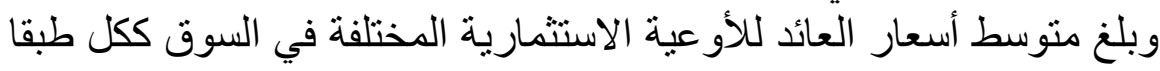

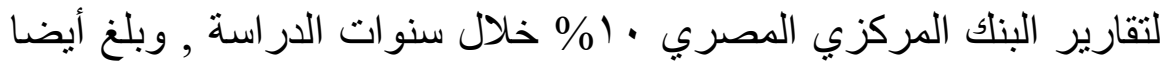


منوسط العائد علي معدلات الاستثمار التي تحققها شركات التامين السوق

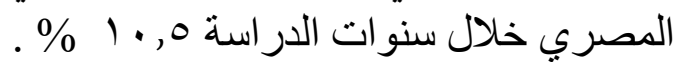

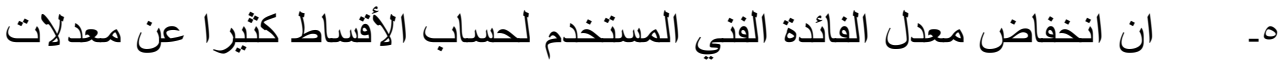

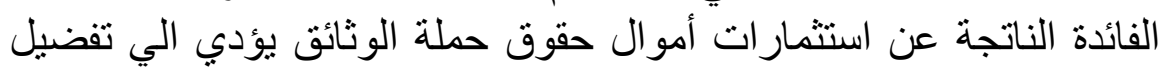

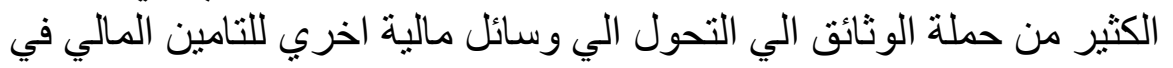

$$
\text { ثناتيا :- التوصيات :- المستقبل . }
$$

ا ـ تكوين او حجز مخصص التقلبات في معدلات الفائدة علي غر ار مخصص التقلبات

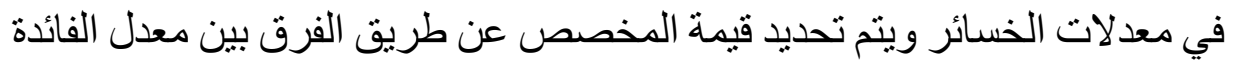

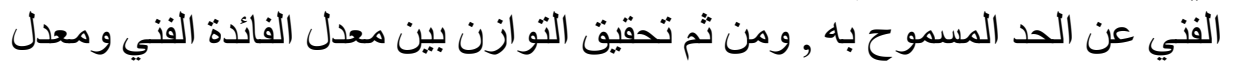

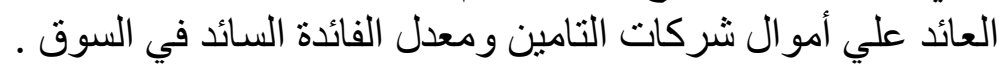

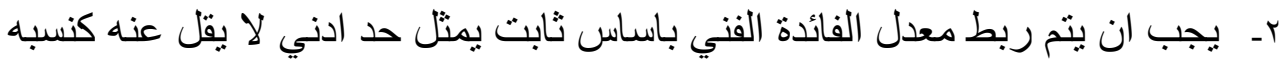

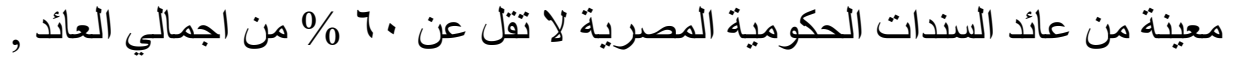
وذللك لانها تتسم بالثبات النسبي . r- يجب اخذ نتائج اعمال شركة التنامين على الحياة وخاصة معدلات النات الاستثمار الفعلية

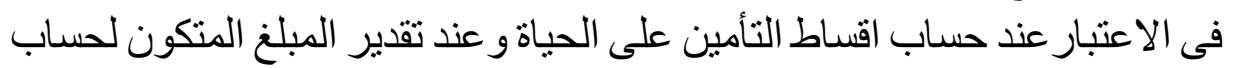
العقد فى نهاية كل سنة الاعنة ع - يجب تعديل او مر اجعة معدل الفائدة الفنى الذى على على اساسة يتم تقدير قسط التأمين فى نهاية كل سنة من سنو اتهعة العقد.

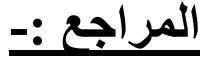

أولا المراجع باللغة العربية :-

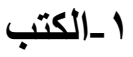

1ـ السيد عبد المطلب عبده، التأمين علي الحياه ،دار الكتاب الجامعي ،القاهره .19V7。

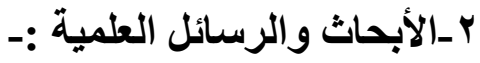

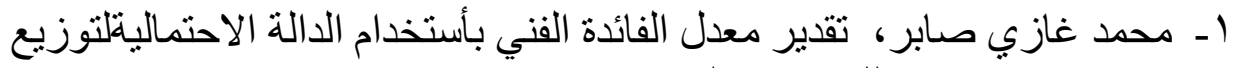

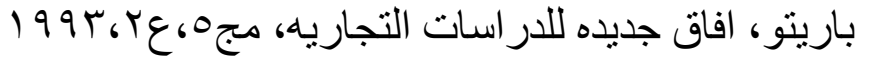




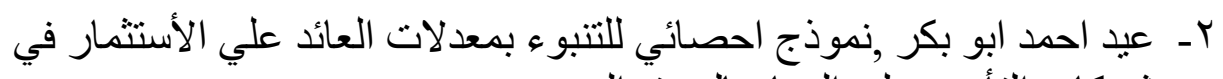

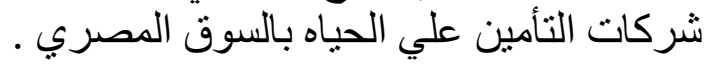

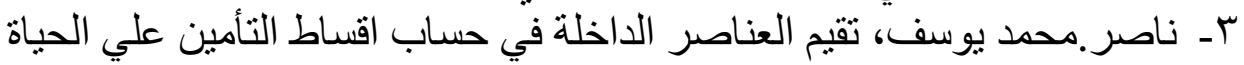

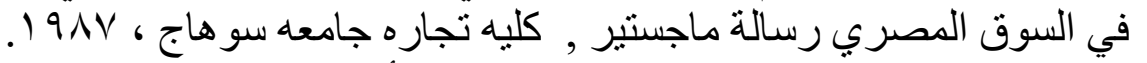

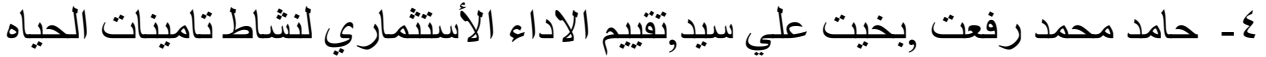

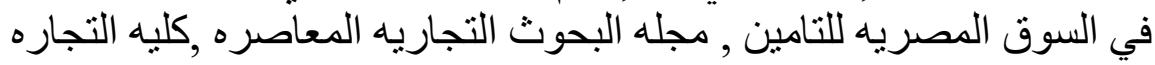

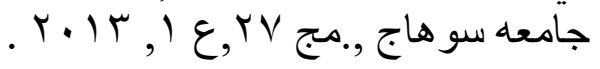

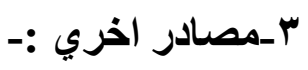

1 - الكتاب الأحصائي السنوي ـ الهيئة العامة للرقابة المالية ـ اعداد مختلفة .

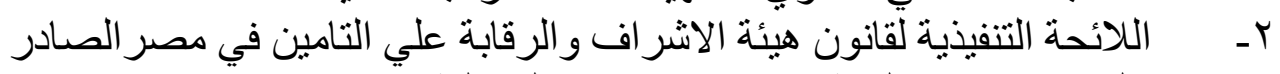

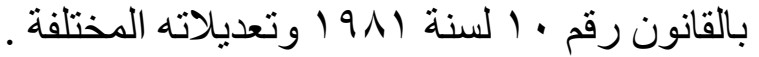

\section{ثانيا المراجع باللغة الإنجليزية :-}

1- Berends, K., McMenamin, R., Plestis, T., \& Rosen, R. J. The sensitivity of life insurance firms to interest rate changes. Economic Perspectives, $r(r), r \cdot I r$.

$r$ - Eling, M., \& Holder, S. Maximum technical interest rates in life insurance in Europe and the United States: An overview and comparison. The Geneva Papers on Risk and InsuranceIssues and Practice, $(r \cdot 1 r$, October) rM(r)

r- Ranna, A., Kivisaari, E., \& Mannonen, H. Determining the Technical Interest Rate in the Finnish Employment Pension Scheme. In Transactions of the 1-th International AFIR Colloquium, Tromso. ( $r \cdots$, June). 